\title{
1973
}

\section{APSA Biographical Directory}

The sixth edition of the APSA Biographical Directory has been published and copies may now be ordered for immediate delivery. The Directory includes complete, up-to-date names and addresses of approximately 12,500 individual APSA members as well as biographical information on over 7,000 political scientists. The Directory also includes appendices classifying members by geographịcal location and fields of interest.

\section{ORDER FORM}

NAME:

ADDRESS:

ZIP

\section{PRICE LIST}

APSA MEMBERS:

Hardback, $\$ 10.00$

Paperback, $\$ 7.50$

NON-MEMBER:

Hardback, $\$ 15.00$

Paperback, $\$ 12.50$

Send form with payment (prepaid) to:

1973 APSA Biographical Directory

1527 New Hampshire Avenue, N.W.

Washington, D. C. 20036 


\section{LOW COST GROUP IISSURANGE AVAILABLE TO APSA MEMBERS}

\section{APSA INSURANCE PLANS}

Group Life Insurance

- $\$ 15,000$ protection with gradual reductions after age 50 .

- Optional Dependent Life Coverage.

Accidental Death and Specific Loss

- Worldwide Coverage.

- Permanent Total Disability Benefits.

Hospital Cash Plan

- $\$ 20$ or $\$ 40$ each and every day hospitalized.

- Payable for up to $\mathbf{3 6 5}$ days for each period of hospital confinement.

- Benefits begin with the first day of hospitalization.

- Daily benefits are doubled if you are hospitalized for cancer.

For further information write to:

Director, Insurence Programs

The American Polftical Sctence Association

1527 New Hampsivire Avenus, N.W.

Woshington, D. C. 20036

\section{CHANGING YOUR ADDRESS?}

If you are planning a move, please fill in the form below and return it to the American Political Science Association,

1527 New Hampshire Avenue, N.W., Washington, D.C. 20036.

Address changes should be received at the Association by the 5th of the month to be included in the monthly update of the Association mailing list.

Name

OLD ADDRESS

NEW ADDRESS

(Zip) (Zip) 
For students of politics and government of all fields of interest

\section{Midwest Political Science Association}

The Midwest Political Science Association is devoted to scholarly and professional interchange, has a national membership and is oriented to the entire discipline.

Membership includes:

- The MIDWEST JOURNAL OF POLITICAL SCIENCE, a respected scholarly quarterly, which publishes the latest research on a wide variety of subjects and reviews outstanding books.

- Annual Meetings, with stimulating programs of current interest. 1973 Annual Meeting May 3-5, Pick-Congress Hotel, Chicago, Illinois.

- Professional placement service at the Annual Meeting at no additional charge.

Annual Dues:

Professional $\$ 10.00$

Student $\$ 6.00$

Family $\$ 14.00$

Retired $\$ 7.50$

Name

Send with remittance to:

Mailing Address

Jean M. Driscoll

Secretary-Treasurer

Zip Code

Midwest Political Science Association

North Park College

5125 N. Spaulding

Affiliation

Chicago, Illinois 60624

Fields of Interest

Checks payable to Midwest Political Science Association 


\section{Registry of}

\section{Retired Professors}

The Association has established a Registry of Retired Professors. The Registry serves as an information exchange for those retired professors who are willing to teach one or more courses on a onesemester or one-year basis, and those institutions desiring to make such appointments. Any retired professor wishing to be listed in the Registry should contact the Association to receive an application form. Departmental chairmen wishing to inquire about the availability of retired professors in a certain specialty or geographic area should write specifying their requirements.
Director, Registry of Retired Professors American Political Science Association 1527 New Hampshire Avenue, N.W. Washington, D.C. 20036 
JUST PUBLISHED BY APSA

\section{A GUIDE TO GRADUATE STUDY IN POLITICAL SCIENCE 1973}

The 2nd edition of the authoritative compilation of Ph.D. and Masters programs in political science, containing information on admissions policies, costs and financial aid, and fields of specialization.

\section{$\$ 2.50$ (prepaid)}

Available Direct From:

American Political Science Association

1527 New Hampshire Ave., N.W.

Washington, D.C. 20036 
Students, professors, and those interested in the study of politics and government are invited to become members of the AMERICAN POLITICAL SCIENCE ASSOCIATION

\section{JOIN APSA}

membership includes:

THE AMERICAN POLITICAL SCIENCE REVIEW-quarterly journal of scholarly articles and book reviews in political science, and

PS—quarterly journal of association news and articles of professional concern

Opportunity to register in the APSA Personnel Service-currently lists the largest number of political science teaching and research positions.

Attend the APSA Annual Meeting, September 4-8, 1973, New Orleans.

Name

Mailing Address

(Zip)

This is an application for membership. Upon receipt of this form we will mail you a membership card and begin a year's subscription to the AMERICAN POLITICAL SCIENCE REVIEW and PS.

Student

Annual

if your annual income is under $\$ 12,000$ $\$ 20$

$\$ 12 \cdot 15,000$

over $\$ 15,000$ $\$ 30$

Please send with remittance to:

Membership Secretary

AMERICAN POLITICAL SCIENCE ASSOCIATION

1527 New Hampshire Ave., N.W.

Washington, D.C. 20036

Add $\$ 1$ for foreign postage. 


\section{APSA HOSPITAL CASH PLAN}

The American Political Science Association announces its new low cost group Hospital Cash Plan designed to provide participants with a cash payment of $\$ 20.00$ or $\$ 40.00$ a day depending upon the program selected. The Plan, underwritten by the Hartford Accident and Indemnity Co., pays for every hospitalized day for up to $\mathbf{3 6 5}$ days for each period of hospital confinement. Benefits are doubled if the participant is hospitalized for cancer.

For further information on the APSA Group Hospital Cash Plan write to:

Director, Insurance Programs

The American Political Science Association

1527 New Hampshire Avenue, N.W.

Washington, D.C. 20036 


\section{THE AMERICAN POLITICAL SCIENCE ASSOCIATION \\ PERSONNEL SERVICE}

The American Political Science Association's Personnel Service operates as a clearinghouse, bringing together political scientists seeking positions and prospective employers. Registration in the service is open to members of the Association and to Political Science Departments. Membership in the Service, which includes a subscription to the monthly Newsletter, is $\$ 6.00$ per year. Membership in the Credential Referral Service of the Personnel Service is an additional $\$ 8.00$.

\section{NEWSLETTER}

A Newsletter, listing openings for political scientists including teaching, administrative and research openings, is mailed monthly to all Personnel Service members. Positions are listed by institution with a brief description of each opening.

\section{CREDENTIAL REFERRAL SERVICE}

A file will be maintained at the Association office for all members of the Credential Referral Service. This file will include a résumé, a dissertation abstract and/or a list of publications, and up to three letters of reference for each member. Referrals are made upon the request of a member or of an institution.

\section{EMPLOYERS USING THE SERVICE}

The Association's Council has adopted a policy that it is a professional obligation of all political science departments to list publicly all vacancies in the APSA Personnel Service Newsletter for which they are recruiting except those vacancies at the association and full professor levels which departments expect to fill from among people known to them. There is no cost to the institution listing its vacancies with the Service. Forms for listing openings in the Newsletter are available from the Personnel Service.

For further information concerning the Personnel Service write to:

Director, Personnel Service

The American Political Science Association

1527 New Hampshire Avenue, N.W.

Washington, D.C. 20036 


\section{The International Political Seience Association Invitation to Membership-1973}

The International Political Science Association welcomes political scientists as members. The Association, founded in 1949, is composed of three categories of members: individuals, institutions and national associations.

Membership in the Association of $\$ 4.00$ a year entitles members to receive the Newsletter giving information about IPSA activities and meetings; to purchase material published under ISPA auspices-including the International Bibliography of Political Science, published annually by Stevens in London and sets of papers submitted at IPSA meetings at reduced cost; and to register at IPSA meetings at lower rates.

Individual members who pay a higher membership fee of $\$ 12.00$ a year are, in addition, entitled to receive either the International Political Science Abstracts published bi-monthly by the Association itself or the International Social Science Journal, the quarterly organ of the Department of Social Sciences of UNESCO. To join the Association send your name and check to the International Political Science Association, 27 rue Saint Guillaume, Paris $7 e$, France. 


\section{FROM THE NATIONAL MUNICIPAL LEAGUE}

Available Fall 1973

Issues of Electoral Reform, Edited by Richard J. Carlson. Ten original essays on voting rights, voter registration and the administration of elections.

1. Voting AND DEMOCRACY

Gerald M. Pomper

Livingston College, Rutgers University

2. THE SUPREME COURT AND VOTING Rights

James F. Blumstein

Vanderbilt University

3. The FeDeral Voting Rights Acts

Richard Claude

University of Maryland, College Park

4. VOTING UNDER THE TWENTY-SIXTH

AMENDMENT

Charlotte Rose, Frontlash, Inc.

Henry Maurer, Philadelphia Federation of Teachers

5. Black Voter Registration in the SOUTH John Lewis

The Voter Education Project, Inc.

6. Professionalizing the Administration of Elections

Richard G. Smolka

The American University

7. COMPUTERS AND ADMINISTRATIVE REForm

W. Edward Weems, Jr.

National Scientific Corporation

8. The Case for Universal Voter

ENROLLMENT

Penn Kimball

The Graduate School of Journalism Columbia University

9. Election Reform: The Perspective of $\mathbf{4 0}$ YeArS

Joseph P. Harris

10. The Electoral Process in America

Richard Scammon, Elections Research Center

Jeanne Richman, National Municipal

League.

Approx. $\$ 3.50$

Also Available

A Model Election System. Recommendations for basic reform of state voter registration procedures and the administration of elections.

Approx. $\$ 2.50$

The Cost of Administering American Elections, Richard G. Smolka, The American University. An analysis of the administrative casts of elections.

Approx. $\$ 3.50$

National Municipal League.

Carl H. Pforzheimer Building

47 East 68th Street, New York, New York 
LONG-TERM PROJECTIONS OF POWER: POLITICAL, ECONOMIC AND MILITARY FORECASTING Oskar Morgenstern, New York University, Klaus Knorr, Princeton University and

Klaus Heiss, Princeton University

Offers projections of the future, to approximately the year 2000 , and examines how these projections may be relevant for guiding research and development in technology for the future environment.

0-88410-008.1 $192 \mathrm{pp}$. October $\$ 9.50$

THE GOVERNMENT AND THE MULTINATIONAL FIRM

John Fayerweather, editor, New York University

Leading international businessmen and academics offer a comprehensive analysis of current thinking about the varied facets of relations between multinational firms and governments.

0-88410-256-4 $144 \mathrm{pp}$. November $\$ 12.50$

MINORITY ENTERPRISE AND THE PRESIDENT'S COUNCIL

Anne Huff \& Samuel I. Doctors, Northwestern University

One component for increased minority participation in the American economy is the President's Advisory Council for Minority Business Enterprise. Doctors and Huff consider the need for PACMBE, outline a detailed plan for minority participation, and look at PACMBE as an example of the presidential advisory process. 0-8410-002-2 $192 \mathrm{pp}$. October $\$ 12.50$

\section{FEDERAL REVENUE SHARING AND THE CITIES}

Ray D. Whitman, University of Maryland

The first full length economic analysis of revenue sharing, offering a history of the revenue sharing proposal, an analysis of the theoretical framework of the proposal, an interpretation of the fiscal and socio-conomic data which bear on the need for and distribution of funds, and studies the effect of revenue sharing on federal, state and local governments. $0-88410-250-5285 \mathrm{pp}$. December $\$ 15.00$

\section{POLITICAL ECONOMICS OF RURAL POVERTY IN THE SOUTH}

Arthur M. Ford, S. Illinois University, Introduction by Robert L. Heilbroner

An approach to the study of poverty which rejects the traditional socio-economic views of poverty that hold "cultural deviation" as its cause. Concludes that a new method is needed to understand the phenomenon, one which comes to grips with the nature and use of power. 0-88410-005-7 $128 \mathrm{pp}$. September $\$ 10.00$

CLEARING THE AIR: FEDERAL POLICY ON AUTOMOTIVE EMISSIONS CONTROL

Henry D. Jacoby, MIT, John Steinbruner, Harvard University

A policy analysis focusing on the series of decisions that now face the government in carrying out its policy on emissions control. Considers the major dimensions of the decisions, develops alternatives to the current policy, and compares the options in terms of their cost and effect on the pollution problem.

$0-88410-301-3288 \mathrm{pp}$. October $\$ 15.00$

\section{ADMINISTRATIVE ALTERNATIVES IN DEVELOPMENT ASSISTANCE}

Gary S. Posz, U.S. Department of State, Jong S. Jun, California State University of Hayward, and

William B. Storm, University of Southern California

Based on extensive interviews with overseas technical personnel of the U.S. Agency for International Development and review of the pertinent literature the authors draw specific conclusions about the effectiveness of AID and offer an application of contemporary organization theory to the problem of constructing a new strategy for world development. 0-88410-004-9 128 pp. September $\$ 10.00$

\section{OIL AND THE OUTER COASTAL SHELF: THE GEORGES BANK CASE}

\section{Foreword by Richard Neustadt}

\section{William R. Ahern, Harvard University}

Deals with the need for more oil and the possibility of off-shore drilling on the Georges Bank. Compares the risks to the environment of drilling as opposed to the uses of tankers and deep-water ports, the costs to consumers, and the technological and geological problems of off-shore drilling.

0-88410-303-x December $\$ 10.00$

\section{THE DYNAMICS OF POPULATION POLICY IN LATIN AMERICA}

\section{edited by Terry L. McCoy, Ohio State University}

A comprehensive analysis of contemporary population policies and programs dealing with fertility and growth. The contributors examine the factors that shape governmental and societal responses to the population challenge and study the actual policies of Columbia, Costa Rica, Chile, Peru, Mexico, Dominican Republic, and Venezuela. 0-88410-350-1 $320 \mathrm{pp}$. October $\$ 15.00$

\section{PSRO: ORGANIZATION FOR REgIONAL PEER REVIEW}

Barry Decker, M.D. \& Poul Bonner, Arthur D. Little, Inc.

Develops conceptual models for the structure and function of prototype Professional Standards Review Organizations as described in the Social Security Amendments of 1972. Review of the pertinent literature and analyzes existing approaches to medical care appraisal. Includes a restatement in non-legal terms of the PSRO legislation. 0-88410-105-3 $384 \mathrm{pp}$. September $\$ 15.00$ 







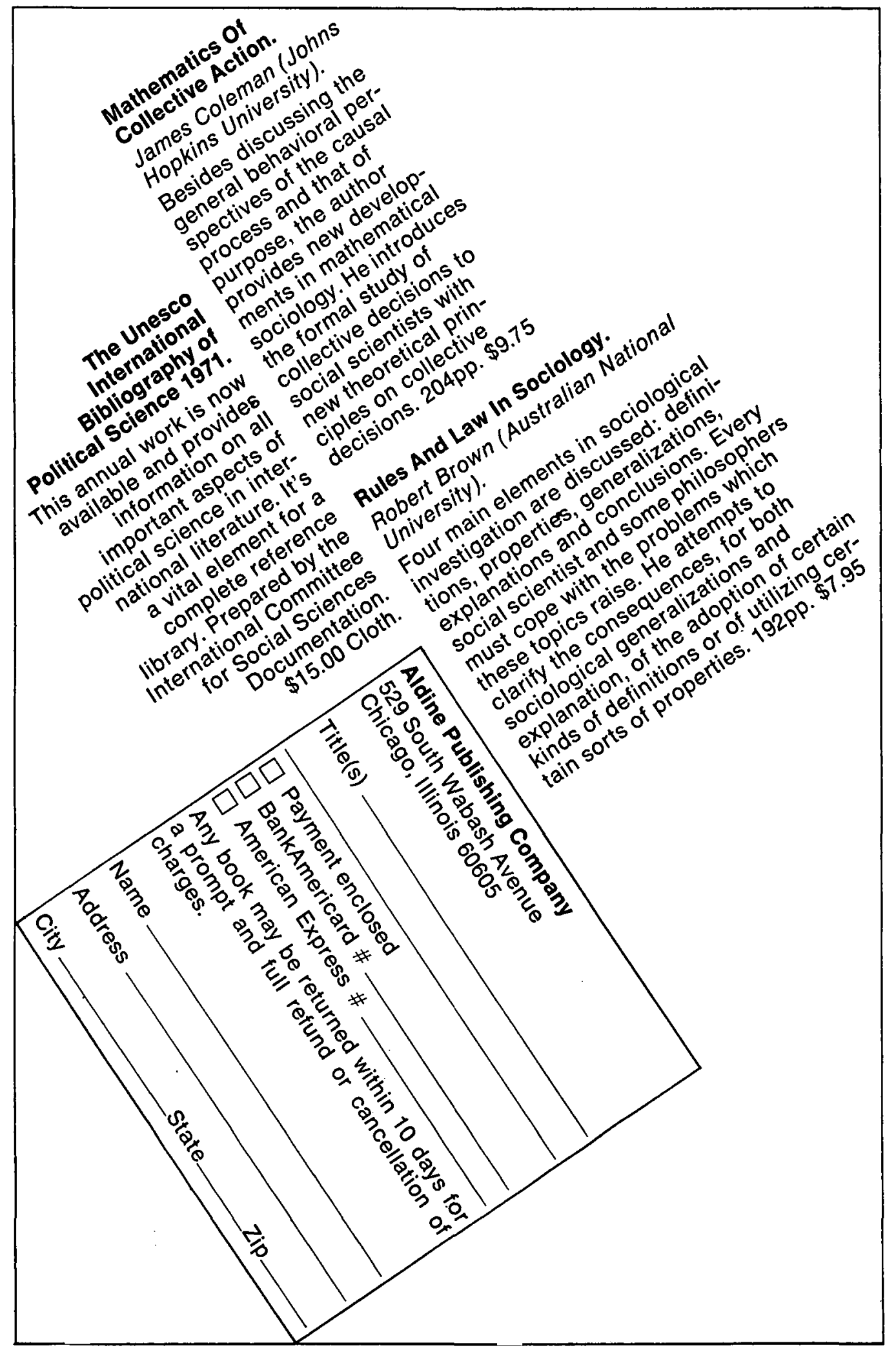




\section{KEEP UP TO DATE IN THE POLITICAL WORLD...}

\section{BILL OF RIGHTS READER}

5th Edition-1973, Revised

Edited by MILTON R. KONVITZ. Revised once again, this well-known book remains a comprehensive, up-to-date survey of the ways in which the freedoms guaranteed by the Bill of Rights have been interpreted by the Supreme Court. Forty-eight new cases are included on such currently pertinent topics as the Pentagon papers, the death penalty, the so-called parochaid legislation, the rights of prisoners and of the poor, and some affirmative action aspects of school desegregation.

THE POLITICS OF CEYLON (SRI LANKA) by ROBERT N. KEARNEY

Focusing on institutional change and adaptation to modernization, this book offers a systematic analysis of the political system of CeyIon (recently renamed the Republic of Sri Lanka) as it has evolved since 1948. Professor Kearney examines the structure and functioning of the legislature, cabinet, and bureaucracy, as well as the nature of the party and electoral systems, election campaigns, and voting. Of particular interest are extended discussions of the 1971 insurrection and the new constitution adopted in 1972.

(South Asian Political Systems series)

$\$ 13.50$

\section{JAPANESE POLITICS-AN INSIDE VIEW Readings from Japan}

Translated and edited by HIROSHI ITOH. Some of Japan's most eminent political commentators and scholars are represented in this collection of nine empirical studies on Japanese policymaking at the local, national, and international levels. Together with the editor's introductions and cogent comments, the essays provide insights into the unique and effective Japanese political system. $\$ 3.95$, paper; $\$ 15.00$, cloth 

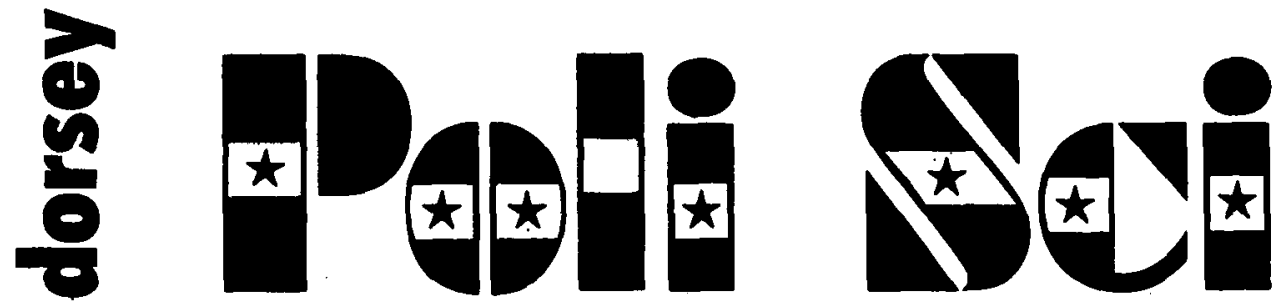

\section{BEHAVIORAL PERSPECTIVES ON AMERICAN POLITICS}

RALPH M. GOLDMAN, California State University, San Francisco

Analyzes the major institutions of American national government from the perspectives suggested by a number of behavioral science concepts, such as linguistics, organization theory, communication, decision making, yet presents traditional American politics material.

$\$ 5.95$ / Paperback

\section{AN INTRODUCTION TO SYSTEMATIC POLITICAL SCIENCE}

DAVID H. EVERSON, Sangamon. State University, and JOANN P. PAINE, Southern Illinois University

Introduces students to the basic concepts of political science at the introductory level, rather than waiting until upper division courses. Focuses on how to think about politics.

$\$ 5.95$ / Paperback

\section{PUBLIC OPINION: MICRO AND MACRO}

\section{JAMES J. BEST, University of Washington}

Examines public opinion from an individual perspective as well as a societal phenomenon. A comprehensive review and critique of the relevant literature in the field.

$\$ 4.95$ / Paperback

\section{AMERICAN FOREIGN POLICY: Response to a Sense of Threat} HENRY T. NASH, Hollins College

America's military response to the threat of Communism since World War $I 1$ has determined foreign policy since that time. Analyzes this response, and examines policy changes through the Strategic Arms Limitations Talks. \$4.95/ Paperback

\section{CASES ON CONSTITUTIONAL LAW: Political Roles of the}

\section{Supreme Court}

VICTOR G. ROSENBLUM, Northwestern University, and A. DIDRICK CASTBERG, California State University, Los Angeles

Covers the political relationships between the Supreme Court and other branches of government, as well as the people and state and local government. Cases preserve as much of the original decision as possible.

$\$ 12.00$

For examination copies write: 


\section{REFORM RULE IN CZECHOSLOVAKIA}

\section{The Dubcek Era 1968-1969}

GALIA GOLAN

"Dr. Golan weaves together an impressive amount of relevant information from Czechoslovak sources in an illuminating, in-depth account of the political and intellectual drama, and provides a scholarly, sensitive interpretation of the Czechoslovak experiment in reform politics." -Perspective. A sequel to Dr. Golan's The Czechoslovak Reform Movement (1971).

$\$ 18.50$

\section{THE SCOTTISH POLITICAL SYSTEM}

\section{JAMES G. KELLAS}

"This book fulfills a longstanding need. It challenges the conventional view of Britain as a unitary, homogeneous polity by convincingly demonstrating the existence of a distinct Scottish political system. This has important implications for the study of British government generally."

Cloth $\$ 12.50$ Paper $\$ 4.45$

\section{THE DYNAMICS OF INDIAN POLITICAL FACTIONS}

A Study of District Councils in the State of Maharashtra MARY C. CARRAS

An analysis of factionalism in two rival groups within the dominant Congress Party. The study suggests that the factional behavior of some 160 councillors interviewed corresponds with national (or calculable) economic interests, thus challenging a common assumption that Indian political alignments are determined by factors such as personal, family or caste loyalties.

$\$ 19.50$

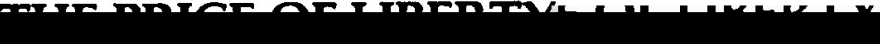

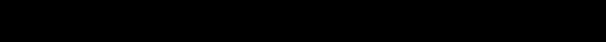

KENIVETH W. J. POST and GEORGED.jeNKNIS

An account of decolonialization in Nigeria which is in part a biography of Adegoke Adelabu, describing both his public personality and the behind-the-scenes political operations. "Gives the reader a fine and vibrant sense of the rough and tumble of Nigerian politics." Perspective

$\$ 27.50$

\section{Cambridge I'niversity Press}

32 East 57th Street, New York, N.Y. 10022 


\section{BALFOUR: A POLITICAL BIOGRAPHY}

SYDNEY H. ZEBEL

Professor Zebel examines the two distinct periods in Balfour's political career: the first covering his service as Chief Secretary for Ireland, Leader of the Conservative Party and Prime Minister; the second as First Lord of the Admiralty, Foreign Secretary and Lord President of the Council. "A fine work of scholarship ... it greatly enhances our understanding of an important British politician."-Library Journal

$\$ 14.95$

\section{TURGOT ON PROGRESS, SOCIOLOGY AND ECONOMICS}

Translated and edited by RONALD L. MEEK

New translations of The Successive Advances of the Human Mind, Reflections on the Formation and the Distribution of Wealth, and On Universal History. Professor Meek's introduction analyzes the interrelationship of Turgot's political, economic and sociological theories. Cambridge Studies in the History and Theory of Politics

$\$ 12.50$

\section{JEAN BODIN AND THE RISE OF ABSOLUTIST THEORY}

JULIAN H. FRANKLIN

"A major contribution to an understanding of Bodin's political ideas."Library Journal. In this new study, Professor Franklin traces the development of Bodin's thought from the tentatively constitutionalist position expressed in his Methodus to the absolutist stand of the Republique, placing in perspective his influence on 17th-century absolutist doctrine.

$\$ 8.95$

\section{TEACHERS' UNIONS AND INTEREST GROUP POLITICS}

\section{DAVID COATES}

A study of the teachers' unions of England and Wales from 1915 to the 1960's. The author differentiates between questions of "behavior" and "influence" and relates the behavior of organized teachers to that of other interest groups.

Cloth $\$ 10.95$ Paper $\$ 4.50$

\section{Cambridge University Press \\ 32 East 57th Street, New York, N.Y. 10022}

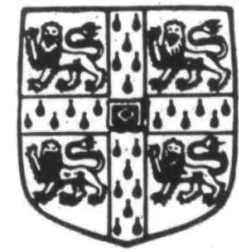




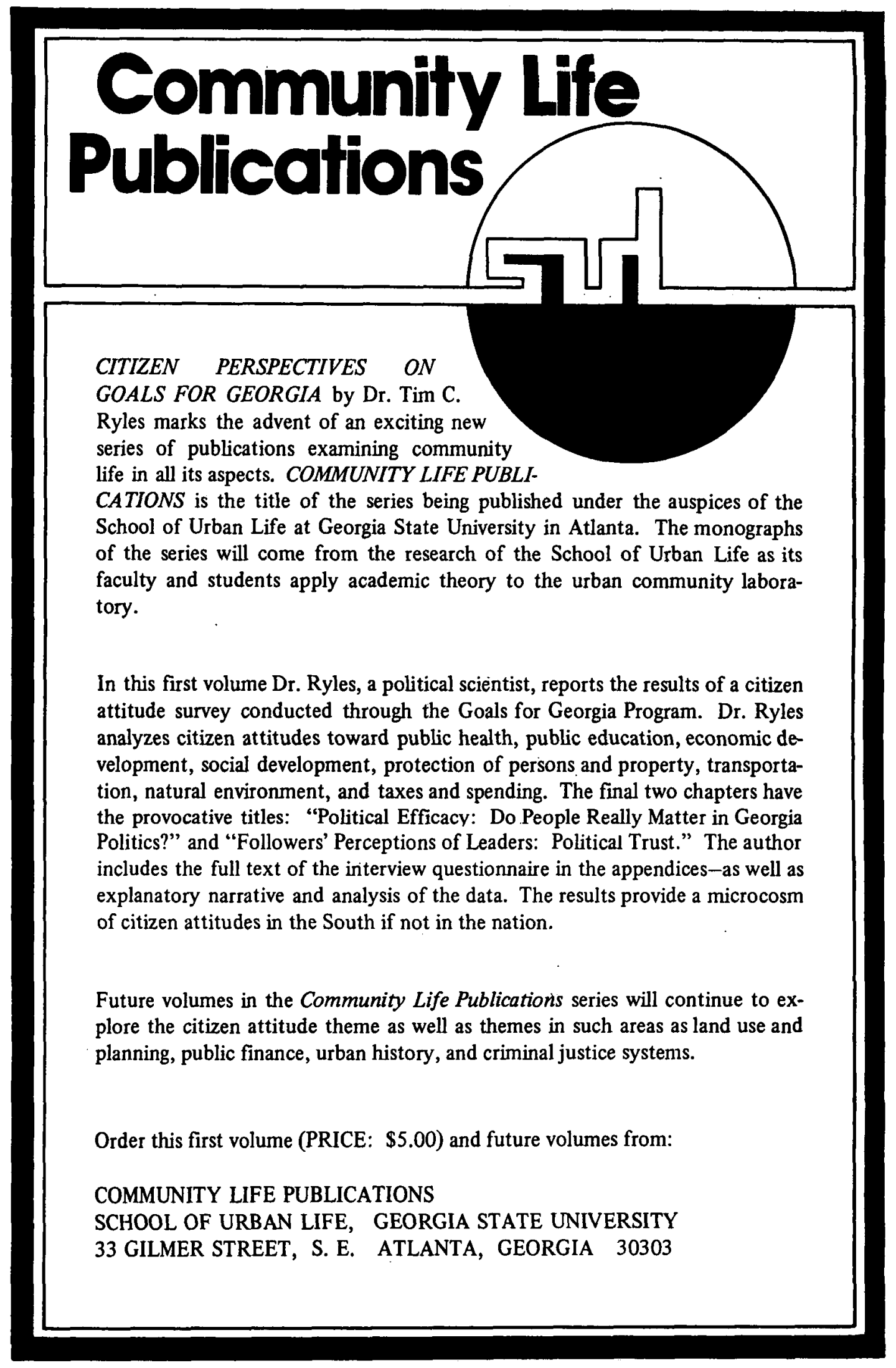



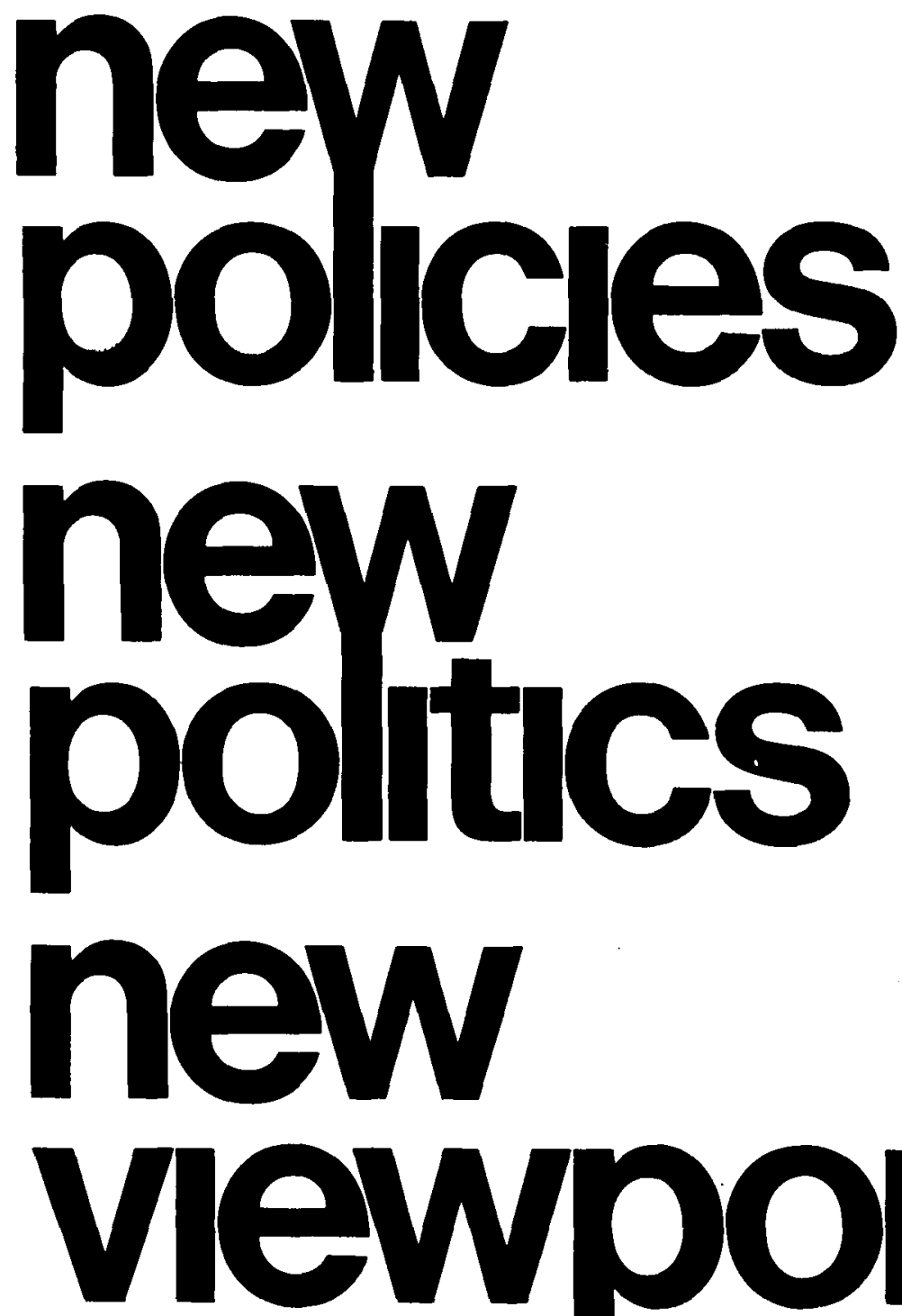

AN END TO HIERARCHY! AN END TO COMPETITION! Organizing the Politics and Economics of Survival Frederick C. Thayer,

University of Pittsburgh

Professor Thayer demonstrates that hierarchy and competition are the fundamental causes of alienation in America today, and that an organizational revolution which will sweep them away is now taking place.

"Professor Thayer has a truly original mind-well worth reading." The Washington Monthly $\$ 2.95$ paperback (05552-3) $\$ 9.95$ cloth (05351-2)
FINANCING ELECTIONS

The Politics of an

American Ruling Class

David Nichols

No book in American political science has so incisively related the question of the class structure in American society to the electoral process and, of timely interest, to the way in which national elections are financed. \$3.95 paperback (05553-1) $\$ 9.95$ cloth (05352-0)

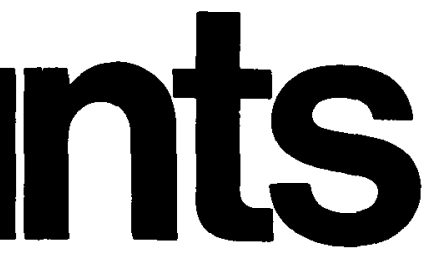

THE GREAT NIXON TURNAROUND:

America's New Foreign Policy in the Post-Liberal Era

Edited by Lloyd Gardner, Rutgers University

Linking the sudden thaw in America's anti-communist policy to the troubled economic situation, Professor Gardner concludes that the Cold War was simply no longer capable of sustaining either America's power or her prosperity. He traces the softening of Nixon's anti-communist rhetoric, and shows why he was the right man to end a Cold War liberals began. $\$ 3.95$ paperback (05551-5)

NEW VIEWPOINTS, A Division of Franklin Watts, Inc., 730 Fifth Avenue, New York, New York 10019 


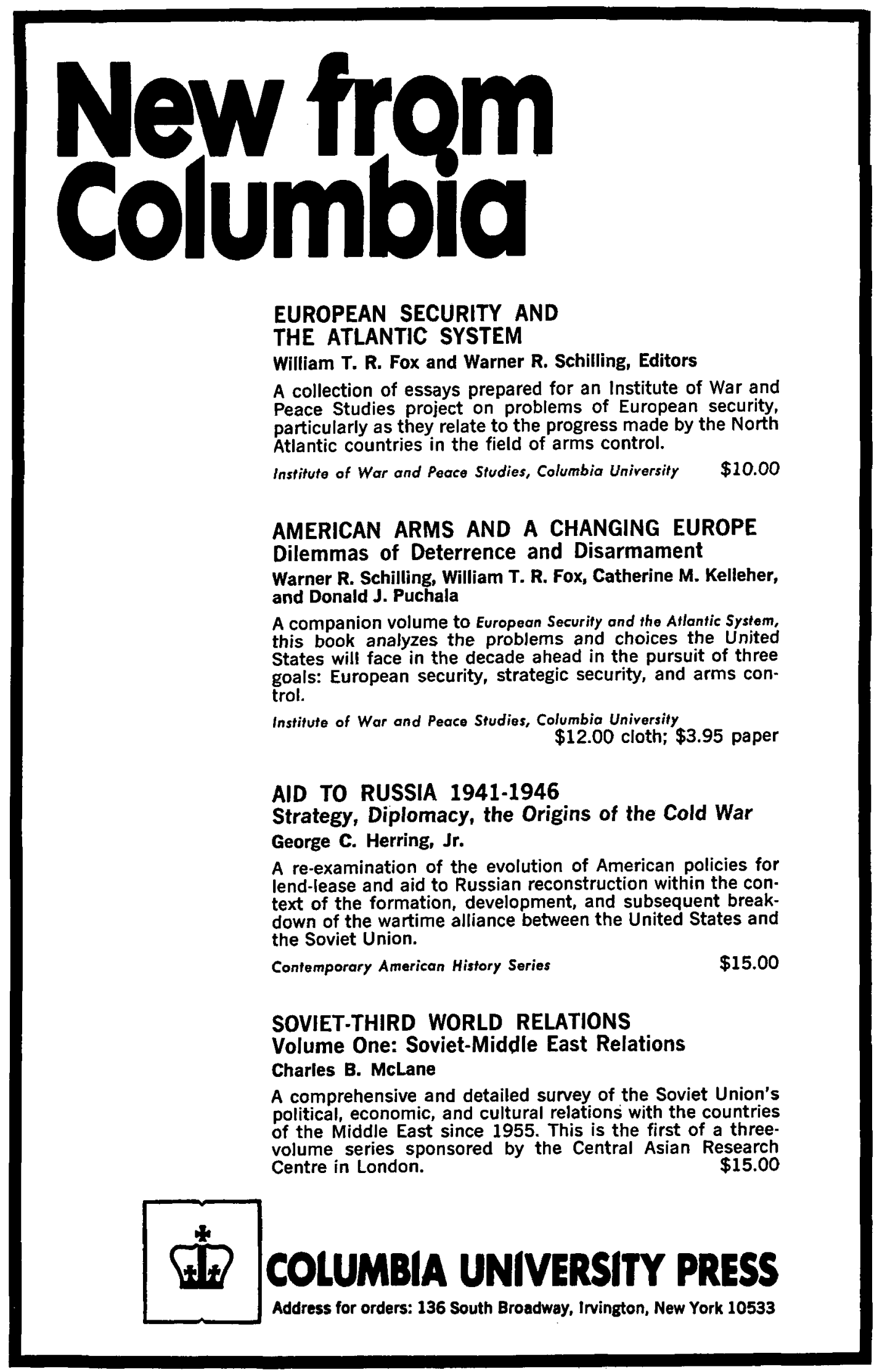




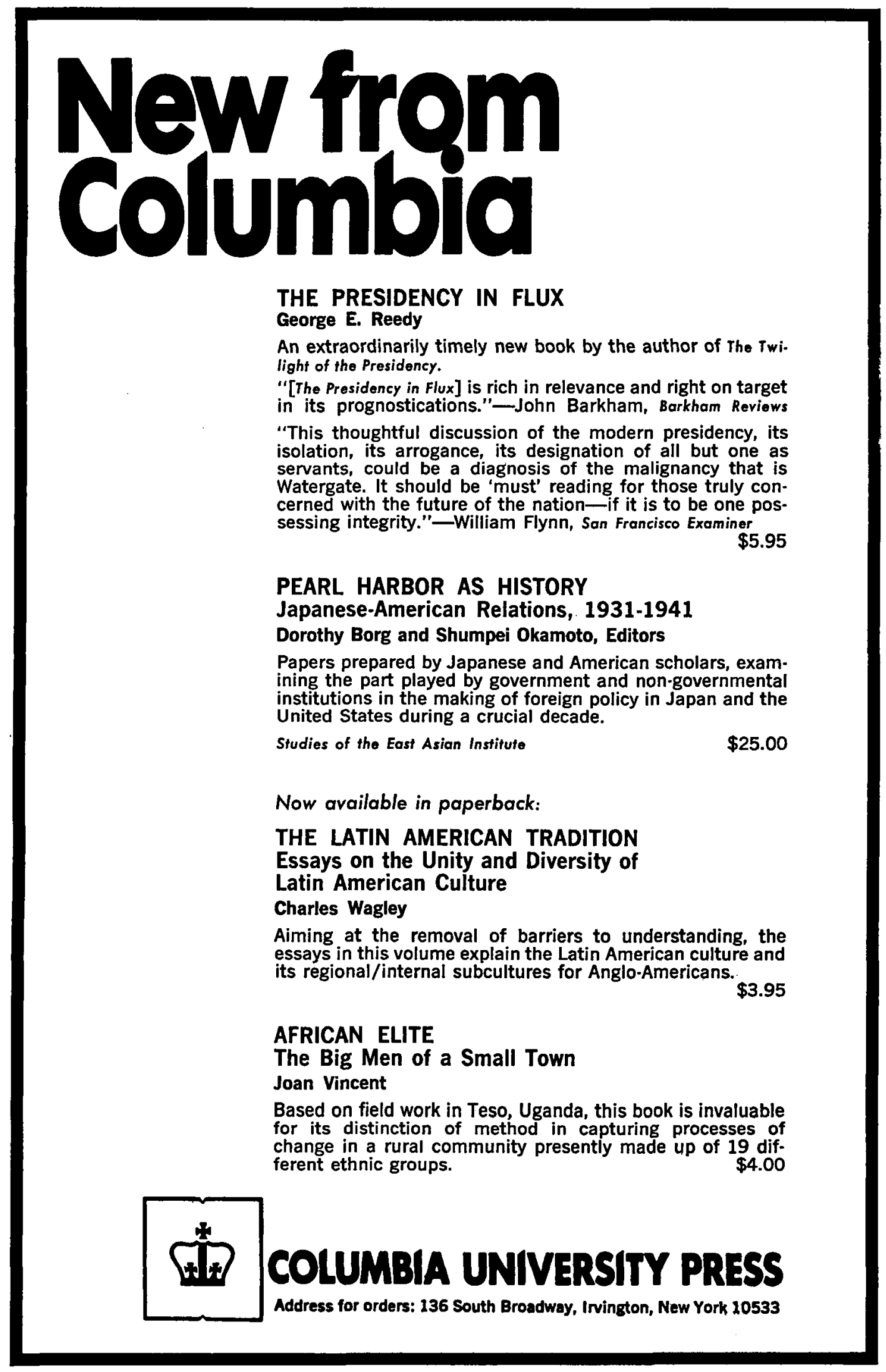




\section{THE GOOD FIGHT}

By Shirley Chisholm. What it was like to be the first black and first woman to run for President: her feelings about party factionalism, black and white conservatism, changing the status quo-and President Nixon. "An idealistic yet hard-headed testament mixing inside stories with hard-won human and political wisdom."-Publishers Weekly. Illustrated. $\$ 6.95$

\section{THE SECOND AMERICAN REVOLUTION.}

\section{Some Personal Observations}

By John D. Rockefeller 3rd. "One of the most penetrating studies on the American society and one of the most courageous." $-U$ Thant "A marvelous job of looking at the many sides of a very complex problem and analyzing them with admirable balance and encouraging optimism."Edwin O. Reischauer. $\$ 6.50$

\section{LETTERS FROM PRISON BY ANTONIO GRAMSCI}

Selected, translated, and introduced by Lynne Lawner. In English for the first time, these letters written during Gramsci's ten years in Fascist jails are "a magnificent introduction to the mind of the twentieth century's greatest Marxist thinker. They teach us how to live and-what comes to the same thing-how to die."-Eugene Genovese. Ilustrated. $\$ 10.00$

\section{JOHN STRACHEY}

By Hugh Thomas. A powerful biography of the brilliant, mercurial British politician and leftist spokesman who died in 1963. Mr. Thomas probes every aspect of his long and varied career, its reflections of leftwing politics in the war and depression-torn 1930s and 1940s, and of postwar British-American relations in the 1950 s. Just published, $\$ 8.50$

\section{EUROPE: THE RADICAL CHALLENGE}

By Hugh Thomas. With uncommon good sense a major political writer looks hopefully toward a united Europe, exploring the problems of Britain's entry into the Common Market, the chances of federalism, the desirability of a unified defense policy, and possible relations with the United States and the Third World. "Wide-ranging and tersely written."Roy Jenkins, British Labour Party. $\$ 8.50$ 


\section{From THE FREE PRESS}

\section{HANDBOOK OF SOVIET SOCIAL SCIENCE DATA}

Edited by Ellen Mickiewicz, Michigan State University

For the first time, the Western scholar can use Soviet data with confidence in its accuracy and exhaustiveness. This pioneering volume brings together massive amounts of data on demography, agriculture, production, health, housing, education, communication, and international interaction in Soviet Society. It is "a fundamentally important work of a kind and quality that has not been available before in the field of Soviet studies ... a major step toward the possibility of true comparative and political analysis."-Karl W. Deutsch, Harvard University, from the Foreword 1973 225 pages

\section{ELECTORAL BEHAVIOR: A Comparative Handbook}

Edited by Richard Rose, University of Strathclyde, Glasgow (with 14 contributors)

This indispensable reference book provides a systematic description and analysis of the relation between social structure, party systems and electoral behavior in major Western nations: the United States, Canada, Ireland, Britain, Germany, Italy, Australia, Norway, Sweden, Finland, the Netherlands, and Belgium.

\section{INTERNATIONAL THEORY AND EUROPEAN INTEGRATION} By Charles Pentland, Queens University, Ontario

This book is a sophisticated and thorough analysis of both theory at the international level and development at the level of European integration. Pluralist, functionalist, neofunctionalist, and federalist approaches are each examined in depth. The author determines not only the areas of compatibility but also the points of difference among these major approaches to integration theory.

1973

\section{THE FREE PRESS}

A DIVISION OF MACMILLAN PUBLISHING CO., INC. 100D Brown Street, Riverside, New Jersey 08075 


\section{New Books for a New Political Science}

\section{ARK II}

Social Response to Environmental Imperatives DENNIS PIRAGES, University of California, San Diego, and PAUL R. EHRLICH, Stanford University
Written by a social scientist and a biologist, this book is intended to put the environmental crisis into social and political perspective and to make the subject of limits to growth understandable to students in the social sciences. The book is unique in its focus on the future and on possible social (as opposed to technological) solutions. Provocative supplementary reading for introductory courses in political science, sociology, economics, environmental studies, social ecology, and other areas.

Publication date: Winter 1973 Paperbound.

A collection of articles by one of the world's foremost authorities on macro-analysis of international affairs. Among the topics discussed are the changing nature of international politics, strategic and military policy, and efforts to develop a peaceful world. Excellent supplementary reading for all courses in international relations and for advanced courses in methodology. Publication date: Winter 1973 Paper and cloth.

Here is the book that those who are interested in nonviolent social change have been searching for. Lakey, a prominent Quaker activist, is specific and concise and offers detailed suggestions for organized action.

"This book gives a clear understanding of nonviolence as an effective means for developing a mass movement for change and leaves no doubt about the hard work required to bring it about." -Cesar Chavez

1973, 234 pages, paperbound, $\$ 2.95$ 
ARMS CONTROL

Readings from SCIENTIFIC AMERICAN

With Introductions by HERBERT F. YORK, University of California, San Diego

Now available as a paperback:

BEYOND THE PUNITIVE SOCIETY

Operant Conditioning: Social and Political Aspects

Edited by HARVEY WHEELER, Center for the Study of Democratic Institutions

\section{THE BELEAGUERED MINORITIES} Cultural Politics in America

S. J. MAKIELSKI, JR., Loyola University

\section{PEACE AND WAR}

Edited by CHARLES R. BEITZ and THEODORE HERMAN

With a Foreword by Alan Geyer, Colgate University

\section{REGIONAL POLITICS AND WORLD ORDER}

Edited by RICHARD A. FALK, Princeton University, and SAUL H. MENDLOVITZ, Rutgers University
Compiled and introduced by one of the most respected authorities in the field of arms control and disarmament, this collection of articles offers a broad introduction to arms control questions that have arisen since the second world war.

1973, 427 pages, 232 illustrations,

cloth $\$ 12.00$, paper $\$ 5.95$

A collection of diverse perspectives on the work of B. F. Skinner and its far-reaching political implications.

"We must decide how much credence to give Skinner's theories. I can imagine no better way to do this than to read the thoughtful evaluations from some of today's leading minds that are gathered together in Beyond the Punitive Society." - Clifton Fadiman

1973,274 pages, cloth $\$ 8.95$, paper $\$ 3.95$

While the old minorities and the political system have been able to accommodate one another during this century, discontent within the "beleaguered" groups of which the author speaks (blacks, Indians, MexicanAmericans, students, and womenl is becoming increasingly obvious. This book is a lucid analysis of the dilemmas these minorities face in seeking political remedies. Important reading for any course in minority and urban studies and for introductory courses in American government and politics.

Publication date: Fall 1973 Paper and cloth.

This stimulating anthology of essays results from the Colgate University Peace Studies program. Many of the readings are by former prominent policy makers and leaders (including Henry $A$. Kissinger, Robert $S$. McNamara, Che Guevara, and John Kenneth Galbraith). The collection's special focus on war and its prevention makes it especially appealing to today's students, who are interested in moral issues as well as the analytical approach to the study of war and conflict.

1973, 435 pages, cloth $\$ 11.95$, paper $\$ 4.95$

This important collection of essays and original material by specialists on various aspects of international relations attempts to provide a basis for fullscale appraisal of the relevance of regional developments to the future of world order. Contributors include Roger Masters, Joseph S. Nye, Ernst B. Haas, and Bruce $M$. Russett.

1973, 486 pages, 7 illustrations, cloth $\$ 12.00$, paper $\$ 5.95$ 


\section{New books on important subjects:}

PARTY AND FACTION IN AMERICAN POLITICS: THE HOUSE OF REPRESENTATIVES, 1789-1801 by Rudolph $M$. Bell. BEGINNINGS

Vast new strata of information are uncovered, and unsuspected coalitions revealed. This quantitative analysis of actual voting records will revise simplistic views of our government's formative years. $\$ 13.95$

AMERICA FOR AMERICANS: ECONOMIC NATIONALISM AND ANGLOPHOBIA IN THE LATE NINETEENTH CENTURY

by Edward P. Crapol. A strident economic nationalism called for commercial independence and for trade domination in this hemisphere. It intensified animosity for England throughout America. "An important contribution. ."-Library Journal \$12.50

LIBRARIES IN THE POLITICAL SCENE: GEORG LEYH AND GERMAN LIBRARIANSHIP, 1933-1953 by Marta L. Dosa.

INFORMATION

Political oppression, total war, and reconstruction brought crises

to individuals and institutions. Original resources from Berlin's archives and Georg Leyh's family have provided insights new in English. $\$ 12.50$

\section{THE UNBOUNDED FRAME: FREEDOM AND COMMUNITY IN NINETEENTH CENTURY AMERICAN UTOPIANISM} by Michael Fellman. Intellectuals of many persuasions sought to invent perfect communities, then disagreed on basic concepts. Analyzes utopian thought from Brisbane through Howells. "An important contribution to American intellectual history."

\section{-Merle Curti $\$ 10.00$}

ART AND POLITICS: CARTOONISTS OF THE MASSES AND LIBERATOR by Richard Fitzgerald. The period from 1911 to 1924 was an uneasy time. Radical publishing flourished in America. Fitzgerald examines five cartoonists and their work, for this study-in-depth: art in service of ideology. 60 illustrations. $\$ 14.50$

FROM CONTRABAND TO FREEDMAN: FEDERAL POLICY TOWARD SOUTHERN BLACKS, 1861-1865 by Louis $S$. Gerteis. Slaves enveloped by Union lines served Federal purposes as a labor pool, regulated to forestall racial agitation. Expedient "emancipation" of blacks brought no real social reform. "A worthwhile addition. . ."-Library Journal \$11.50

AMERICAN GUNBOAT DIPLOMACY AND THE OLD NAVY, 1877-1889 by Kenneth J. Hagan. What were the purposes of policing the world with old wooden warships: expansionism, ideology, commerce-or all of those? This well-rounded study is of value in comprehending the period. "The author has succeeded notably. . . Scholarly history at its best!" 
HUMAN MEMORY AND KNOWLEDGE: A SYSTEMS

APPROACH by Glynn Harmon. Man's structures for the organization of knowledge follow a design constricted by his capacity for short-term memory. This analysis points toward means of predicting specific advances in knowledge. $\$ 9.50$

\section{SAMUEL GOMPERS AND THE ORIGINS OF THE AMERICAN FEDERATION OF LABOR, 1848-1896 by Stuart Bruce Kaufman. \\ Analysis of writings by Gompers and those nearest him reveals \\ Gompers' true intent was to modify Karl Marx's European design to suit the American circumstance. Will enliven a continuing debate. $\$ 11.50$}

THE IMAGE OF THE ARMY OFFICER IN AMERICA: BACKGROUND FOR CURRENT VIEWS by C. Robert Kemble.

This book surveys changes in America's at titudes toward its

\section{MILITARY}

military careerists. Opinions from Washington's and Jefferson's to Mumford's and Mailer's are cited. "Unique and valuable contribution to the literature on the subject."

-Library Journal $\$ 10.75$

TRAMPS AND REFORMERS, 1873-1916: THE DISCOVERY OF UNEMPLOYMENT IN NEW YORK by Paul T. Ringenbach.

Since Plymouth Rock, the vagrant had been thought to be a willful social threat. Not until the panics of 1893 and 1907 did reformers see correlation between the prevalence of tramps and the scarcity of jobs. $\$ 10.50$

ROOTS OF MARYLAND DEMOCRACY, 1753-1776 by David Curtis Skaggs. A widespread poor tenantry, denied vote or office, surged in democratic revolution against the gentry leadership.

Skaggs' conclusion is clear: many Marylanders fought the War of the Revolution primarily to change prevailing structures within the colony. $\$ 12.00$

THE TARIFF, POLITICS, AND AMERICAN FOREIGN POLICY, 1874-1901 by Tom E. Terrill. With neither one dominant, both major parties spotlighted tariff levels. Republicans aimed high,

Democrats low. Then, boom and bust convinced both parties that prosperity hinged on foreign trade, and required an expansionist consensus. $\$ 12.00$
EBONY KINSHIP: AFRICA, AFRICANS, AND THE AFRO-

AMERICAN by Robert G. Weisbord. Black nationalism in America grows out of a 150 -year search for black dignity, identity, prosperity.. This book documents that search. Foreword by Floyd B. McKissick. "Worthwhile reading, especially since material on . . the topic is so rare." -Library Journal $\$ 10.95$

\section{TARIFFS}

\section{RACIAL PRIDE}

\section{Available from

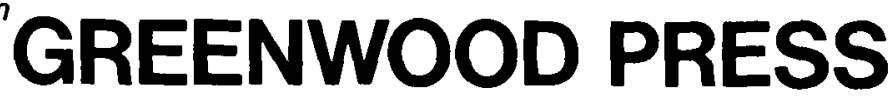

a division of Williamhouse-Regency Inc.

51 Riverside Avenue, Westport, Connecticut 06880 


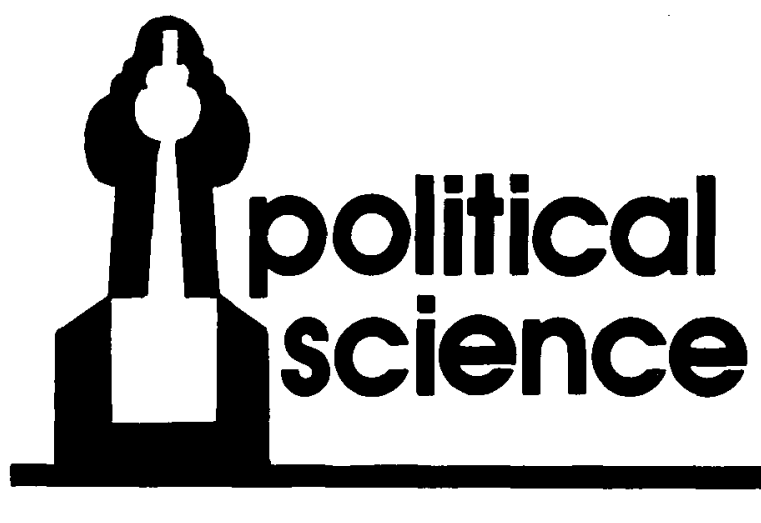

\section{MODERN PUBLIC ADMINISTRATION, Third Edition}

\author{
FELIX A. NIGRO \& LLOYD G. NIGRO
}

The Third Edition of this comprehensive introduction to public administration has been thoroughly updated to include recent developments in the field. All chapters have been significantly revised, and a new chapter on values and public administration has been added. Written in nontechnical language, the book covers both theory and practice and relates administration to the social and other environments of government and to politics and the policy-making process. 468 pp.; $\$ 9.95$. October, 1973.

\section{TRADITION AND IDENTITY IN CHANGING AFRICA \\ MARK A. TESSLER, WILLIAM M. $O^{\prime} B A R R$, \& DAVID H. SPAIN}

This unique volume discusses the broad issues confronting three different African peoples experiencing rapid social change. The resulting identity crises are viewed from all levels of the $80 \mathrm{clal}$ system through an integrated set of fleld studies. Each comparative account is presented in a common format and with a common theoretical focus. Empirical data which goes beyond the case study material introduce generalizations relevant to a broad range of issues. Tentative: 368 pp.; \$4.95: paper. October, 1973.

\section{PARTICIPATION IN AMERICA: Political Democracy and Social Equality \\ SIDNEY VERBA \& NORMAN H. NIE}

428 pp.; $\$ 10.00 .1972$.
New/Recent Volumes in

HARPER'S COMPARATIVE

GOVERNMENT SERIES

Michael Curtis, Advisory Editor

IDEOLOGY AND CULTURE:

An Introduction to the

Dialectic of Contemporary

Chinese Politics

JOHN BRYAN STARR

Using principles of both western and Chinese political thought, this book provides a balanced introduction to contemporary Chinese government and politics. Political life in China at the local, regional, and national levels is described and interpreted. Similarities to other political systems are fully discussed. 320 pp.; $\$ 3.50$ : paper. July, 1973.

\section{NIGERIAN POLITICS}

JOHN M. OSTHEIMER

202 pp.; \$2.95: paper. January, 1973.

\section{FRENCH POLITICS AND POLITICAL INSTITUTIONS, Second Edition \\ ROY PIERCE}

368 pp.; \$3.50: paper. May, 1973.

\section{POLITICAL DEVELOPMENT: A General Theory and a Latin American Case Study HELIO JAGUARIBE}

603 pp.; \$11.95. January, 1973. 


\section{India's Revolution \\ Gandhi and the Quit India Movement \\ Francis G. Hutchins}

Gandhi's Quit India movement of 1942 climaxed a nationalist revolutionary movement which sought independence on India's own terms. The author maintains that independence was attained through revolution, not through the benevolence of the British Imperial regime, and he uses the Indian case to develop a general theory of the revolutionary nature of colonial nationalism.

$\$ 14.00$

\section{Politics in War}

\section{The Bases of Political Community in South Vietnam}

Allan E. Goodman

Politics in War deals mainly with the years 1967-1970, but bears on the problems South Vietnam faces now that American forces are no longer active. Mr. Goodman has based his analysis of how the Vietnamese saw the period of deepest American involvement on firsthand research, including over three hundred interviews with Vietnamese political leaders and government officials.

$\$ 12.50$

\section{Revolutionary Politics in the Long Parliament}

\section{John R. MacCormack}

The author provides a fresh and coherent interpretation of the events chronicled in the first volume of S. R. Gardiner's monumental History of the Great Civil War. This is the first systematic study of the politics of five crucial years of the Puritan Revolution, the period between John Pym's death in December, 1643, and the execution of Charles I in January, 1649. $\$ 14.00$

\section{Minorities Under Communism \\ Nationalities as a Source of Tension Among Balkan Communist States}

Robert R. King

The author explores the impact of major national minorities in southeastern Europe from 1945 to the present. Included are discussions of post-World War II conflicts over borders, methods employed to reduce the appearance of national minorities, and use of historical controversies to advance claims to adjacent territories and populations.

$\$ 14.00$

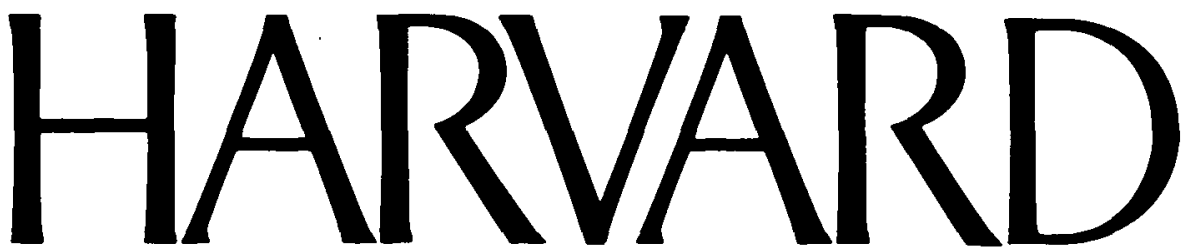

HARVARD UNIVERSITY PRESS, 79 GARDEN STREET, CAMBRIDGE, MASSACHUSETTS 02138 


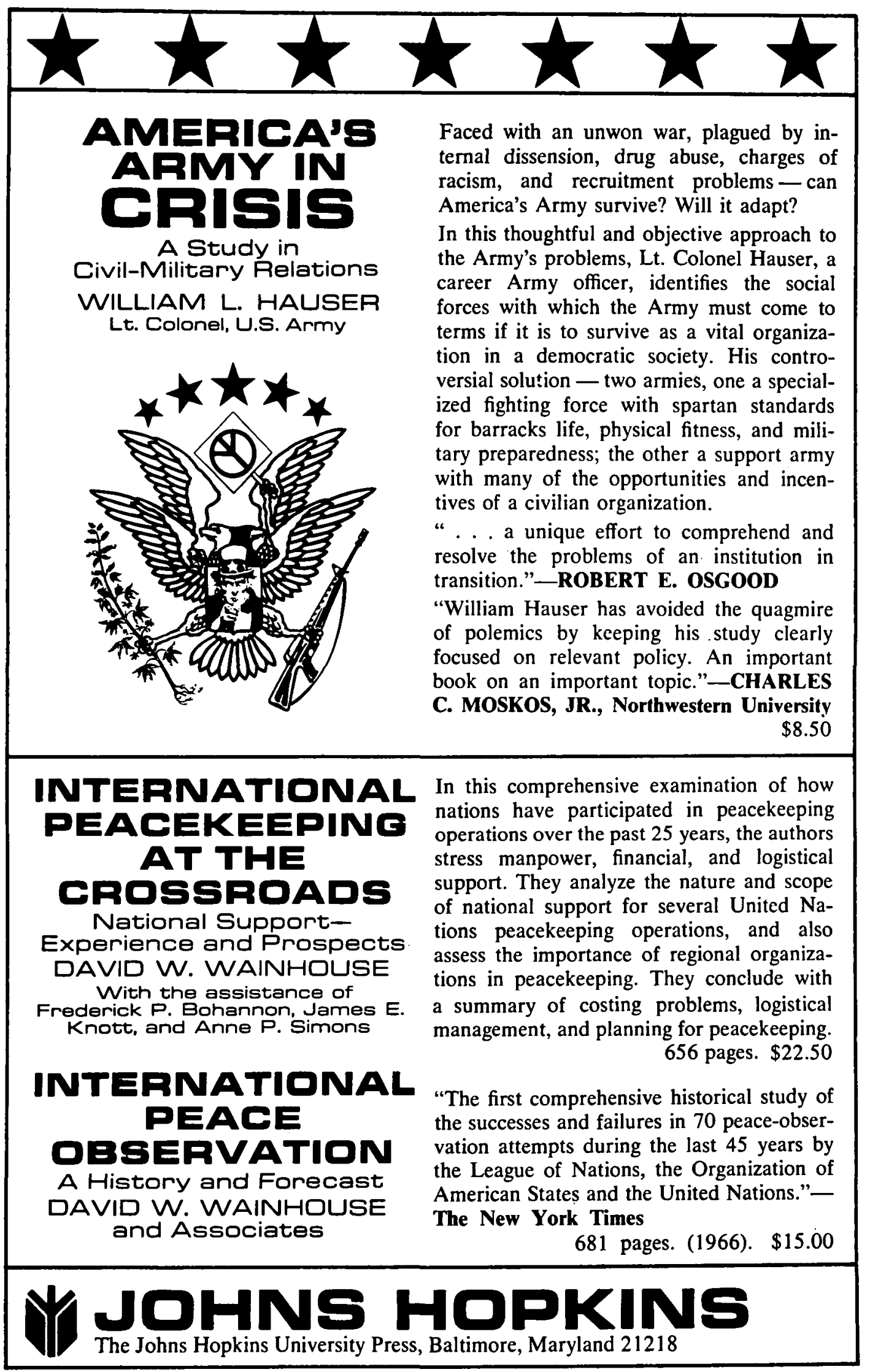




\section{Zaw School of 酸arbard annibersity Cambrioge, Alass. 02138}

\section{Liberal Arts Fellowships in Law}

For the academic year 1974-1975 Harvard Law School offers four or five Liberal Arts Fellowships to college and university teachers in the arts and sciences for a year at the Law School. Holders of these Fellowships will have the title of Fellow in Law and . . (History, Sociology, Political Science, Economics, Philosophy, etc., depending upon their particular discipline).

The purpose of the fellowships is to enable teachers in the social sciences or humanities to study fundamental techniques, concepts, and aims of law, so that, in their teaching and research, they will be better able to use legal materials and legal insights which are relevant to their own disciplines.

Fellowship holders will presumably take at least two first-year courses in law, in addition to more advanced courses, and will participate in a joint seminar. The year of study will not count toward a degree.

The fellowship grant is sufficient to cover tuition and fees. The Chairman of the Liberal Arts Fellowship Committee will be glad to write a letter to any funding agency to which the applicant has applied describing the Program and indicating the extent of the Committee's interest in inviting the applicant to be a Fellow.

Applications should include a biographical résumé (including academic record and list of publications), a statement explaining what the applicant hopes to achieve through his year of study, and two letters of recommendation.

Applications for 1974-1975 should be submitted before January 15, 1974, to the Chairman, Committee on Liberal Arts Fellowships, Harvard Law School, Cambridge, Massachusetts 02138.

Awards will be announced before February 15, 1974. 

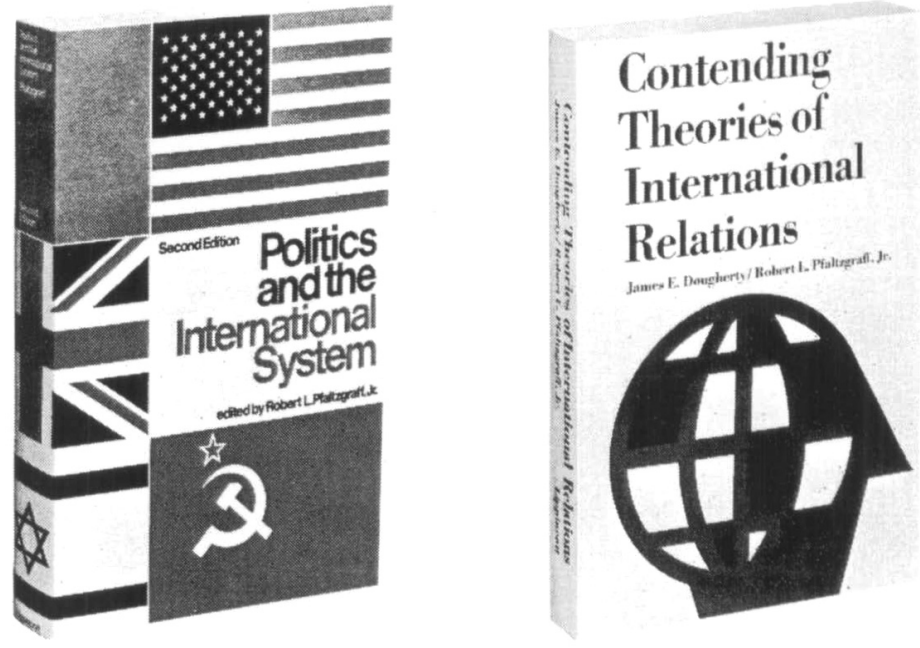

\section{WORTH}

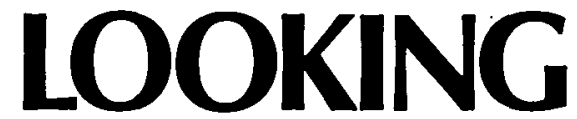

INTO

\section{POLITICS AND THE INTERNATIONAL SYSTEM}

\section{Second Edition}

Edited by Robert L. Pfaltzgraft, Jr., Fletcher School of Law and Diplomacy, Tufts University

Ten new selections reflecting the impact of current international tensions, recent technological progress and research are included in this revised edition. The selectionsforty-two in all-include some of the most important writings on the nature and scope of international relations as a discipline, and on the study of international phenomena. 614 pages/1972/paperbound, $\$ 6.50$

\section{CONTENDING THEORIES OF INTERNATIONAL RELATIONS}

James E. Dougherty, St. Joseph's College (Pa.), and Robert L. Pfaltzgrafi, Jr, Fletcher School of Law and Diplomacy, Tufts University

This highly useful book is both an overview and a synthesis of international relations theory. Theories of conflict, war and revolution are thoroughly discussed. Pacifism, imperialism, balance of power, realist theory, man-milieu relationships, international systems theory, theories of international integration, decision making, theories of conflict and deterrence, disarmament and arms control, are all presented in their historical context.

“... exhibits a remarkable scope and range. But most importantly, through it all the book remains provocative and readable."

"...provides a comprehensive and reliable guide to the study of international relations as a whole." -International Affairs 416 pages/1971/clothbound, $\$ 9.95 /$ paperbound, $\$ 6.25$ 


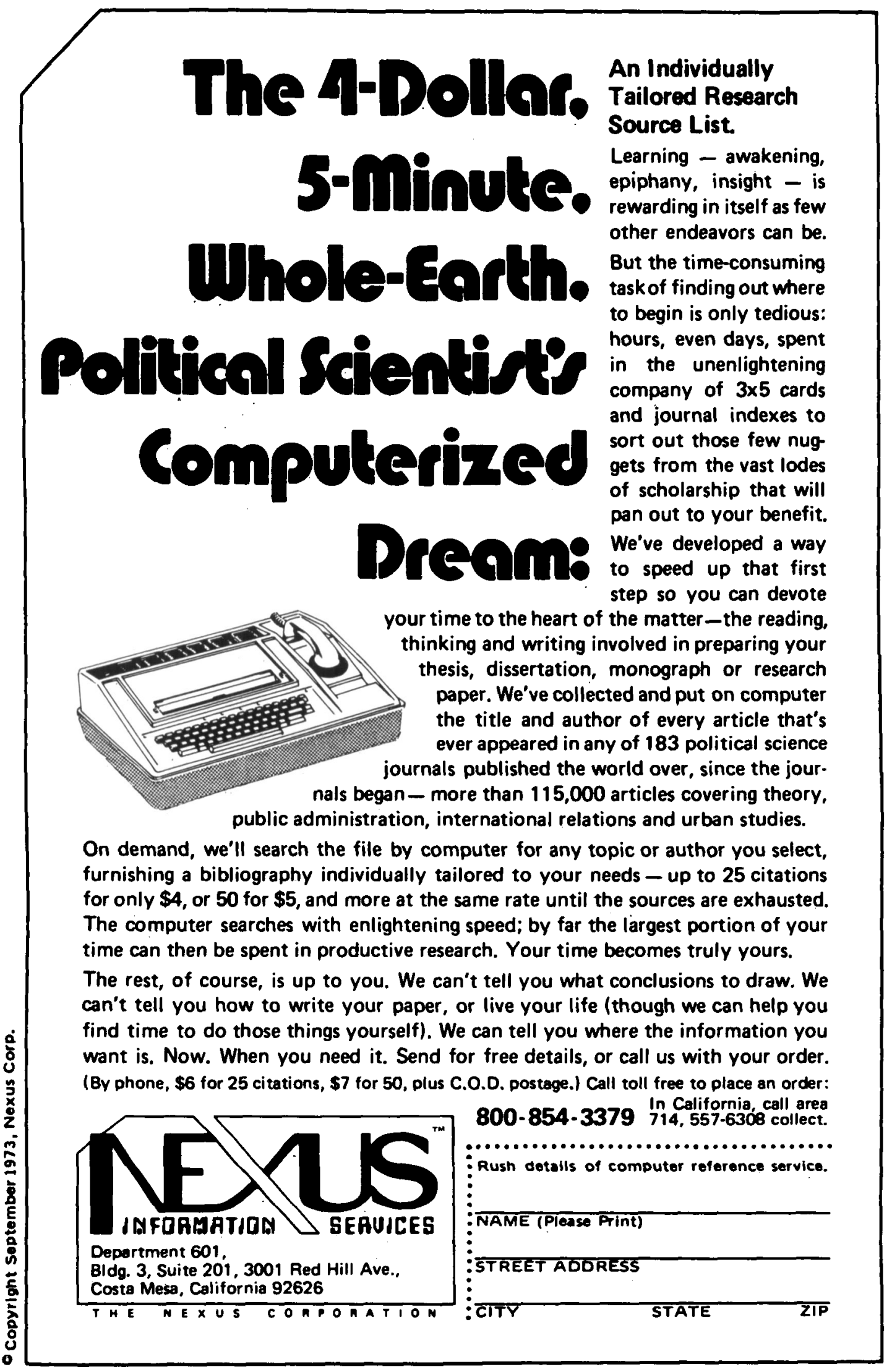




\title{
QUASI-EXPERIMENTAL APPROACHES
}

Testing Theory and Evaluating Policy

\author{
edited by James A. Caporaso and Leslie L. Roos, Jr.
}

These nine interrelated essays explore the use of quasi-experiments with short- and long-time-series data. General essays and specific case studies compare quasi-experimental and more traditional approaches. The examples are drawn from a number of fields, including comparative politics, international relations, organizational behavior, and environmental studies. 325 pages

cloth: $\$ 15.00$ paper: $\$ 3.95$

\section{THE POLITICAL INTEGRATION OF URBAN SQUATTERS by Marc Howard Ross}

\begin{abstract}
The booming urban centers in the developing areas of Africa, Asia, and Latin America represent both the promise and the frustration of rapid social change. Drawing on national and international theories of political integration, Professor Ross outlines the process by which a squatter settlement in Nairobi, Kenya, led by former Mau Mau freedom fighters, developed into a politically integrated community where most observers would expect to find disorganization.

265 pages

\section{SURVEY RESEARCH IN AFRICA}

\section{Its Applications and Limits}

edited by William M. O'Barr, David H. Spain, and Mark A. Tessler

At a time when Western researchers working in Africa have been charged with insensitivity to African problems and with distorted and ethnocentric research priorities, the problems involved in crossing cultural lines to conduct social research are many and varied. After an introductory essay discussing the history of survey research and the recent turmoil surrounding it in Africa, the papers explore the ethical, epistemological, and methodological implications of applying Western techniques to African research problems.

336 pages

cloth: $\$ 15.00$

paper: $\$ 4.95$

\section{ELITE AND SPECIALIZED INTERVIEWING by Lewis Anthony Dexter}

From his virtually unique experience in the field of elite interviewing, the author has distilled a number of recommendations about the mechanics of the interview process: how to approach a prospective subject, how to conduct the interview, and how to record it. Working toward a "transactional" theory of interviewing, Dexter investigates the effects that the interviewer himself has on the person being interviewed and on his responses.

205 pages

cloth: $\$ 7.50$ paper: $\$ 3.25$ 


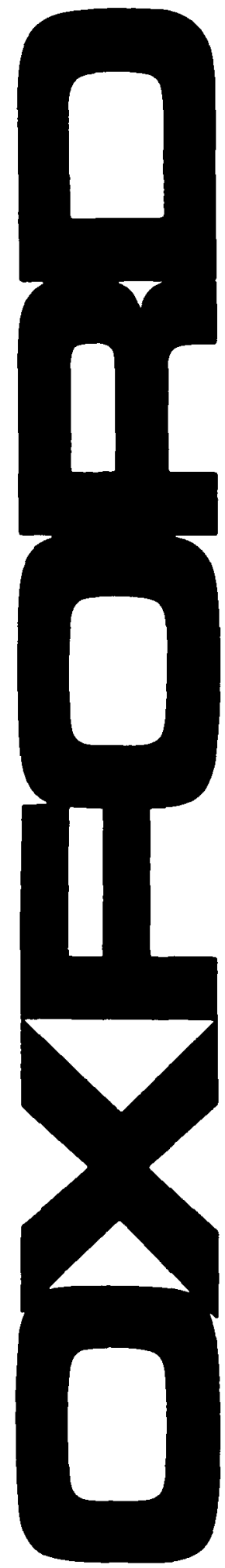

The Liberal Theory of Justice

A Critical Examination of the Principle Doctrines

in "A Theory of Justice" by John Rawls

BRIAN M. BARRY. $\square$ A critical exposition of John Rawis" "A Theory of Justice," this volume sets Rawls' theory in its intellectual context and provides a systematic account of its basic features. Dr. Barry examines Rawls' claim to have formulated a logical deduction of two principles of justice, and discusses Rawls' most important economic and political deductions.

1973 cloth $\$ 9.75$

paper $\$ 3.50$

\section{Documents on International Affairs 1963}

Edited by D. C. WATT, JAMES MAYALL and CORNELIA NAVARI. $\square$ Major developments in international affairs during 1963 are covered in this volume, including: Berlin's role in East/West German relations; the Soviet Union's conflict with Communist China; the war in Yemen; the United States' involvement in Viet Nam; the Federation of Malaysia; and the Inter-American Committee on the Alliance for Progress.

(Royal Institute for International Affairs)

$1973 \quad 624 \mathrm{pp}$. $\$ 32.00$

\section{The Bases of International Order}

\section{Essays in Honour of C. A. W. Manning}

Edited by ALAN JAMES. $\square$ In this extensive and systematic inquiry various aspects of the interaction of states within a basic international order are examined. Among the topics discussed are the relationship between order and change at the international level; the question of whether war is a threat to or a support of international order, or both; and the contribution of contemporary theorists to our understanding of the bases of international order.

$1973 \quad 224 \mathrm{pp}$. $\$ 11.25$

\section{Pakistan's Foreign Policy}

An Historical Analysis

S. M. BURKE. $\square$ "Professor Burke has written a better defence of Pakistan's foreign policy than any Pakistani has ever achieved. He has pace, lucidity, a mastery of his material. He uses innumerable

quotations, and always effectively....Professor Burke should be read." -The Economist

$1973 \quad 450 \mathrm{pp}$. $\$ 20.25$

\section{Pan-Africanism and Nationalism in West Africa 1900-1945}

\section{A Study in Ideology and Social Classes}

J. AYODELE LANGLEY. $\square$ Using much previously unpublished material, the author analyzes the origins of Pan-African politics in western Africa and investigates nationalist ideology and social classes in the area. He also examines the reception of black American ideologies and the ways in which they were modified by the economics of nationalism and by the conservative leadership of the lawyer-merchant class.

(Oxford Studies in African Affairs)

$1973 \quad 416 \mathrm{pp}$. $\$ 21.00$

\section{Racial Bargaining in Independent Kenya}

A Study of Minorities and Decolonization

DONALD ROTHCHILD, University of California, Davis. $\square$ In a study of race relations in modern Kenya, the author focuses on the dynamic processes of interracial bargaining and conflict resolution among the three main racial communities during the pre- and post-independence periods. (Institute of Race Relations)

$1973 \quad 496 \mathrm{pp}$. $\$ 22.50$

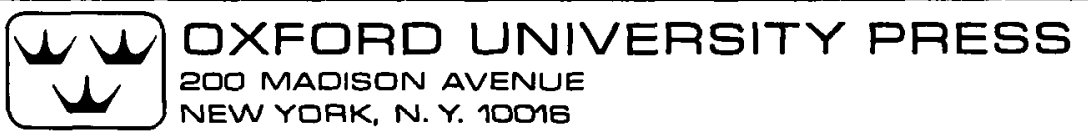




\section{PHILOSOPHY OF THE SOCIAL SCIENCES}

Editors

J. O. Wisdom, John O'Neill, Harold Kaplan, I. C. Jarvie, J. N. Hattiangadi

Volume 3, Number 1, March 1973

Ernest Gellner

Scale and Nation

A. D. Smith

'Ideas' and 'Structure' in the Formation of Independent Ideals

John King-Farlow

Pronouns, Primacy and Falsification in Linguistics

Michael Ruse

The Nature of Scientific Models: Formal versus

Material Analogy

John W. Yolton

Action Theory as the Foundation for the Science of Man

Subscriptions to:

Aberdeen University Press, Farmers Hall, Aberdeen, Scotland AB9 2XT

Manuscripts to:

Editorial Secretary, Department of Philosophy, York University, 4700 Keele Street, Downsview, Ontario, Canada.

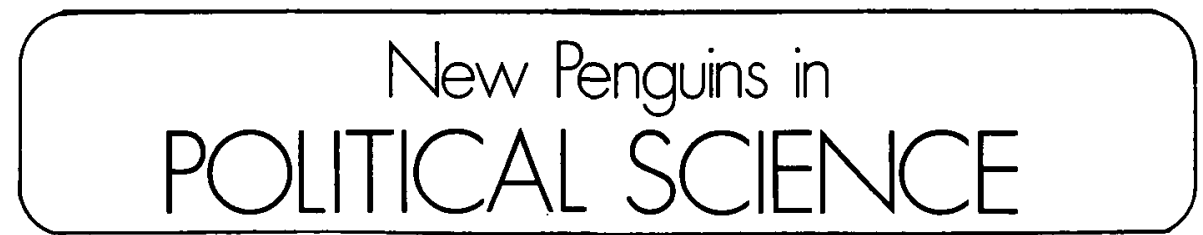

HOW THE GOVERNMENT BREAKS THE LAW. Jethro $K$. Lieberman. A documented, non-partisan report on crime at all levels of the American government. \$1.95

ROOTS OF WAR. Richard J. Barnet. The first comprehensive survey of the men and institutions behind U.S. foreign policy. \$1.65

C.I.A.: The Myth and the Madness. Patrick J. McGarvey. An insider's view of the world of American intelligence operations. \$1.65

IN SEARCH OF NIXON. Bruce Mazlish. This psychohistorical inquiry uncovers the deepest levels of President Nixon's personality to explain why he feels, thinks, and behaves as he does. $\$ 1.50$

COLD WAR AND COUNTERREVOLUTION. Richard J. Walton. A radical re-evaluation of President John F. Kennedy's foreign policy. \$1.45

For a complete list of Penguin books in political science, write:

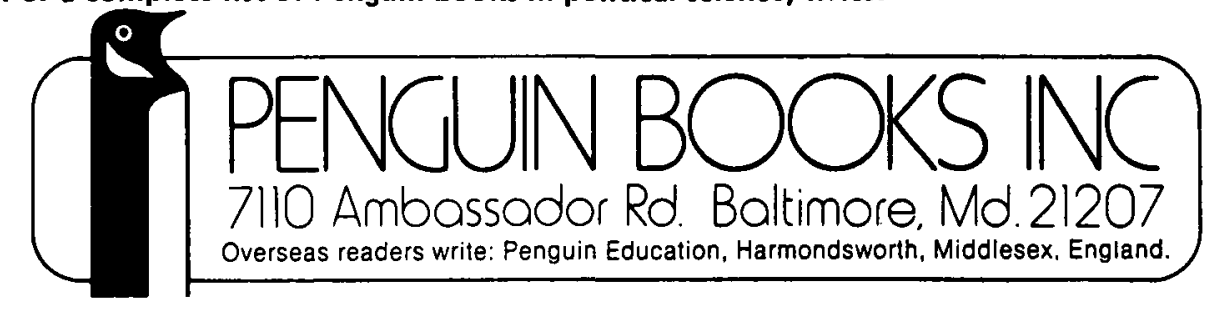




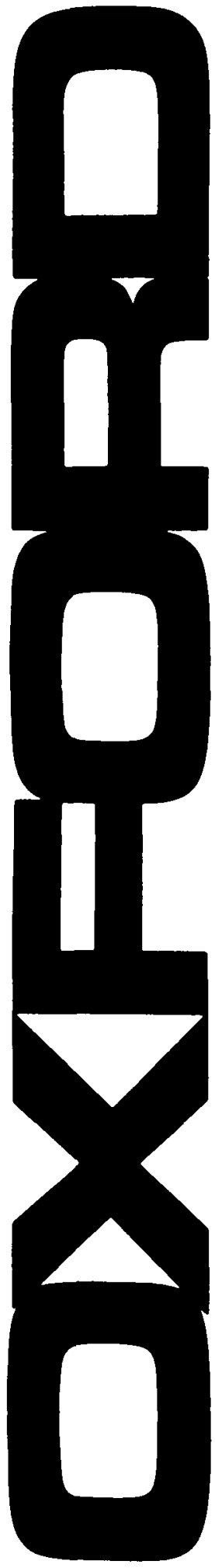

\section{The Impact of Supreme Court Decisions}

\section{Empirical Studies}

\section{Second Edition}

Edited by THEODORE L. BECKER, University of Hawaii, and MALCOLM M. FEELEY, New York University. $\square$ "An excellent supplement to texts with a traditional case orientation. Students can use the book to understand that law is not necessarily what Justices say it is." - Anthony Champagne, Rutgers University, Livingston College. "Again-a splendid collection." -Richard J. Richardson, University of North Carolina
1973
256 pp.
paper $\$ 2.95$

\section{The New Federalism}

MICHAEL D. REAGAN, University of California, Riverside. $\square$ "This is a well written book, consistent in its logic, and both realistic and optimistic in its suggestions."-Daniel Barbee, Georgia State University. "An excellent book to serve as the focal point stimulus for one of America's present day problems-Federalism."-John M. Nickerson, University of Maine $1972 \quad$ (paper, 1973) 192 pp. cloth $\$ 5.95$

paper $\$ 1.50$

\section{Freedom and the Court}

Civil Rights and Liberties in the United States

Second Edition

HENRY J. ABRAHAM, University of Virginia. $\square$ "This is one of the best books available in the area of comparative courts and judicial institutions." -Michael J. Horan, University of Wyoming. "As expected, Professor Abraham has again produced the best book on civil liberties. His new material makes the book all the more interesting."-David M. Atkinson, University of Maryland $1972 \quad 416$ pp. cloth $\$ 12.50 \quad$ paper $\$ 3.95$

\section{Word Politics}

Verbal Strategy Among the Superpowers

THOMAS M. FRANCK, New York University, and EDWARD WEISBAND, State University of New York, Binghamton. $\square$ "Putting it quite simply, Word Politics is a very good book. It is brief, well written, interesting, and worthwhile. . . . The authors have harmoniously blended case studies, logical analysis, theoretical analysis, and policy prescription. Moreover, the context of superpower relationships makes the book quite relevant."-Richard B. Finnegan, The American Political Science Review

$1971 \quad$ (paper, 1972) $192 \mathrm{pp}$ ) cloth $\$ 5.95 \quad$ paper $\$ 1.95$

\section{Contemporary International Theory and} the Behaviour of States

JOSEPH FRANKEL, University of Southampton. $\square$ The aim of this book is to introduce the reader to theoretical ways of thinking about international relations; it concerns itself with what theory is for and about, not what it actually is. The volume concentrates heavily upon the behavioral approaches and, within them, upon the role of values and the concept of "national interest."

1973

144 pp.

cloth $\$ 4.00$

paper $\$ 1.95$

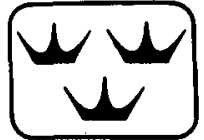




\section{New Paperbacks from Praeger}

URBAN POLITICS AND PUBLIC POLICY

The City in Crisis

Edited by Stephen M. David, Fordham University, and Paul E. Peterson, University of Chicago

This imaginative new reader illustrates how deficiencies common to most urban political systems affect the formulation of public policy in our cities. The book is divided into three sections. The first defines and analyzes three of the most glaring of these inadequacies-the autonomy of urban bureaucracies, the existence of multiple governments, and limited access to political processes given groups with little power. The second section examines the effects of these deficiencies on four key policy areas-land use, law enforcement, education, and transportation. Section three presents a series of proposals for solving the problems defined and illustrated in the first two sections of this collection.
1973
$354 \mathrm{pp}$.
$\$ 3.95$ paper

\section{THE POLITICS OF ENVIRONMENTAL CONCERN}

Walter A. Rosenbaum, University of Florida

This book draws together the basic elements of environmental politics: the nature and gravity of the ecological threat; the roles played in pollution politics by politicians, government agencies, businessmen, and public interest groups; conflicting ideologies and resulting concerns; and current administrative practices and legislative developments at the federal, state, and local levels. The contributions and boon-doggling of $\mathrm{HEW}$, Interior, and Agriculture departments, and the Council on Environment Quality; the tenuous position of the Environmental Protection Agency; and the conflicts among ecologists and the public are weighed throughout. The book concludes with an assessment of what needs to be done-and what action may be possible.

$1973 \quad 306 \mathrm{pp}$.

$\$ 3.95$ paper

\section{BOTH YOUR HOUSES}

\section{The Truth About Congress \\ Warren Weaver, Jr.}

"The Capitol is a hall of illusions, peopled by the myths that the legislative branch remains proudly coequal, that Congress continues to serve the nation well, that the old ways are sufficient to the tasks of the new day. None of this is true," writes
Warren Weaver, Jr. This book tells the story of the deterioration of Congress. The author uncovers the weaknesses that have brought both houses to their current parlous condition, and he proposes some practical remedies. He discusses such topics as the shortcomings of the committee system, the importance of rules and customs in both houses, the role of the conference committee, congressional ethics, and how Congress handles its financial and foreign policy responsibilities. Warren Weaver, Jr., is a congressional and national correspondent of The New York Times.

September, $1973 \quad 318$ pp. $\$ 2.95$ paper

\section{GOVERNMENT AND POLITICS IN AFRICA}

Leslie Rubin, and Brian Weinstein, Howard

University

This work adopts a unified approach to the complexities of the contemporary African political scene. The authors first examine pre-colonial and colonial social and political institutions. They look at colonialism's effects on traditional systems, the different forms of opposition that emerged, and the relatively swift and peaceful return to autonomy. After discussing the areas still under European control, the authors turn to the major tasks confronting independent Africa in an analysis of problems of economic development and political growth. Finally, there is discussion of the independent states' efforts to achieve African unity and the continent's role in world affairs. January, $1974 \quad$ ca. 320 pp. $\$ 4.95$ paper

\section{THE MIDDLE EAST}

Nations, Super-powers and Wars

Yair Evron

This realistic analysis of the Arab-Israeli conflict provides a reasoned discussion of the deeper courses of the confrontation, its mechanisms and motivations, and the policies and strategies of the two sides. The Author concentrates on the actions and tangible interests of the adversaries rather than on their ideologies or moral claims. Part I gives a brief historical view of the conflict from 1948 to 1971 . Part II describes the role of the super-powers and the structure of the relations between the nations of the Middle East. The Author is attached to the Van Leer Institute of Jerusalem, where he is director of its project examining the future of the Arab-Israeli relations.

August, $1973 \quad 244 \mathrm{pp}$.

$\$ 3.50$ paper 


\title{
Princeton announces a major new series \\ to encourage the application of mathematical methods to historical analysis
}

\author{
Sponsored by the History Advisory Committee of the \\ Mathematical Social Sciences Board
}

Now Available

THE DIMENSIONS OF QUANTITATIVE RESEARCH IN HISTORY

Edited by William 0 . Aydelotte, Allan G. Bogue, Robert William Fogel

14 authorities discuss the uses of mathematical methods in historical research. Ranging through social, economic and political history in England. France and the United States, their essays present the freshest and technically most promising work now being done. Each offers a concrete demonstration of the advantages and limitations of this new approach. 436 pages. $\$ 13.50$
ESSAYS ON

A MATURE ECONOMY

Britain after 1840

Edited by Donald N. McCloskey

Seventeen essays apply modern economic theory and statistical methods to Britain's economy from the peak of her industrial dominance to 1920, showing that "the new economic history... is now a recognized and exciting part of modern social science."-Choice.

"Valuable for its... insights into the nature of the problems involved in the growth process." - The Times Literary Supplement

439 pages. $\$ 12.50$

\section{Forthcoming}

Race and Slavery in the Western Hemisphere

The History of Legislative Behavior

The New Urban History
International Comparison of Social Mobility in Past Societies

International Trade and Internal Growth
Quantitative Studies of Popular Voting Behavior Government and Education: Policies, Expenditures and Consequences Studies of Political Elites

New from Princeton:

AN INTRODUCTION TO QUANTITATIVE METHODS FOR HISTORIANS

by Roderick Floud 220 pages. $\$ 7.50$ 


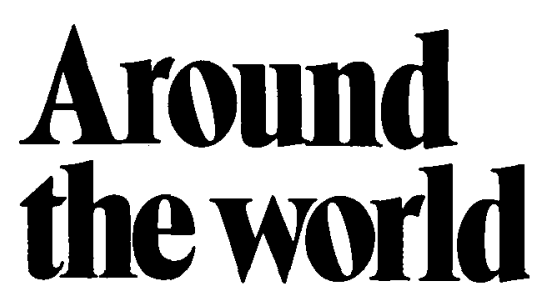

The

United Nations and the

Superpowers

U.S.SOVIET

INTERACTION

AT THE UN.

THIRD EDITION

John Stoessinger

City University of New York

\section{A NEW EDITION JUST PUBLISHED!}

Concluding that no single nation or group of nations controls the U.N., but that all use it to pursue their own national interests, Professor Stoessinger maintains:

"The key to a rejuvenation of the U.N.... must be sought at the political level in a commitment by the member states, especially the two superpowers and China, to use the U.N. rather than to by-pass it and let it atrophy."

The text focuses on how China's entrance into the U.N., the controversies between have and have-not states, and the emergence of new nations have affected the position and usefulness of the U.N.

Random House August, 1973

256 pages $\$ 3.50$ paperbound
Pditics

Among Nations THE STRUGGLE ROR POWER AND PEACE FIFTH EDTION

Hans J. Morgenthau

HONORED AUTHOR. DISTINGUISHED CLASSIC.

Professor Morgenthau has updated this work with an eye to the changes in the

balance of power and influence. The theoretical section has been enlarged to differentiate between usable and unusable power and between power and influence. The growing world concern over nuclear power and environmental problems is also examined. Knopf, $1972 \quad 615$ pages $\$ 9.95$

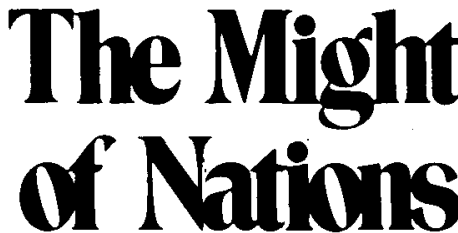
WORLD POLITICS IN OUR TIME FOURTH EDTION John Stoessinger City University of New York

The winner of the 1963 Bancroft Prize in International Relations on first publication, The Might of Nations continues to be an objective authority

on world politics. The case studies covering Bangladesh, the Mid-East, and Indo-China, and the discussion of such

issues as the world ecological crisis update the text. This edition maintains that as China emerges, the post-war era of bi-lateral confrontation is being replaced by one of tri-angular oppositions.

There are chapter bibliographies.

Random House January, 1973 480 pages $\$ 6.95$ paperbound 
Patterns of Gowernment

THE MAICR POITICAL SISTEMS OF EUROPE THIRD EDTTYN

Samuel Beer, Adam Ulam, Guido Goldman, all of Harvard University, and Suzanne Berger of Massachusetts Institute of Technology

\section{ANNOUNCING-Five paperbound volumes available this Spring!}

Retains the same in-depth treatment found in the hardcover edition *, but offers you greater teaching flexibility and more teaching alternatives.

There is one volume for each of the five sections (entirely new on France, Germany, and England, and updated on the U.S.S.R.) in the recent third edition. The paperbacks reprint each of these in full, and those dealing with Britain, France, and Germany have been expanded.

\section{Beer-Modern Political Development $\$ 2.95$ paperbound \\ Ulam-The Russian Political System $\$ 2.95$ paperbound}

Beer-The British Political System $\$ 2.95$ paperbound

Berger-The French Political System \$2.95 paperbound

Goldman-The German Political System \$3.95 paperbound

Select only the volumes covering the material you cover!

*Available if you prefer the single-volume structure.

\section{Macropolitics ina Global Society} Richard W. Sterling Dartmouth University COMING THIS WINTER!

Aimed at the first course in international relations, this new text studies the international system from a global point of view.

Maintains that: ... although national and regional interests are legitimate they must be measured in terms of how well they meet the growing needs of the world as a whole.

... there must be a redistribution of power, wealth, status and education

if a reasonably peaceful world society is to be maintained.

Includes:

... an entire chapter on global ecology ... data and analysis relevant to 1970-2000 (utilizing data and research from 1965-1973)

... comprehensive treatment of such phenomena as multinational corporations, contemporary international monetary problems, and the current status of armament and arms control

... analysis of both sociological and ideological developments (e.g., population pressures are studied as carefully as major power rivalries) ... detailed appendices Knopf February, 1973 500 pages $\$ 10.00$

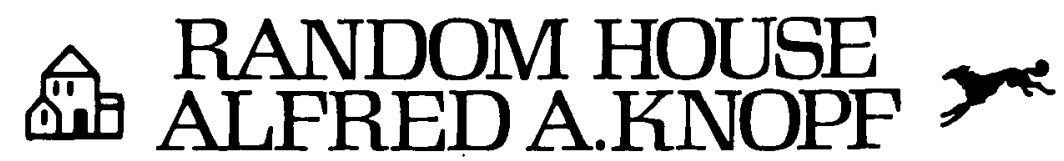




\section{Courts, Judges and Politics}

Walter Murphy, Princeton

University and Herman Pritchett, University of California at Santa Barbara

\section{COMING THIS SPRING!}

The second edition of a pioneering volume in the field of American judicial politics. Combining analytic essays by the editors with readings drawn from sources such as Supreme Court cases, historical documents, and personal letters of statesmen, this text explores the political significance of the judiciary's activities. There is also an entire section on judicial ethics.

Each chapter includes an introduction summarizing the important principles and issues around which the following readings are grouped, and headnotes precede each selection.

Random House February, 1974

768 pages $\$ 10.95$

\section{Americais Pdilitical System FEDERAL}

Peter Woll and Robert Binstock both of Brandeis University

ADOPTED IN OVER 200 SCHOOLS

This successful American government text was written with the student in mind.

It examines the American political system by utilizing both extensive textual material and readings drawn from outside sources.

Includes:

... case studies drawn from various sources

... annotated bibliographies

... essay and discussion questions

... illustrations and diagrams

Random House 1972

628 pages $\quad \$ 6.95$ paperbound

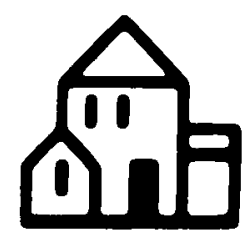

THE COLLEGE DEPARTMENT.

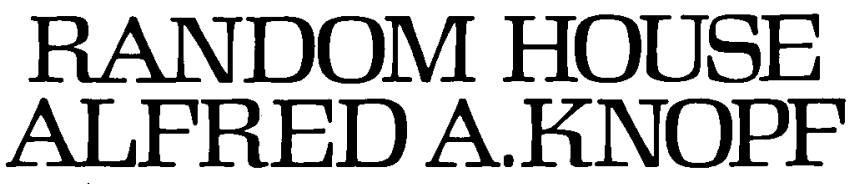

457 HAHN ROAD, WESTMINSTER, MARYLAND 21157 


\section{American Politics and Pullic Policy}

\section{Edited by Michael P. Smith Boston University}

An anthology focusing on the tension in American politics between pluralism and populism. Selections range from Norman Mailer's "The Siege of Chicago" to an excerpt from Joe McGinness's The Selling of the President, 1968.

Random House 1973

448 pages $\$ 4.95$ paperbound

\section{Civil Rights}

Richard Pious, York University

Racism. Poverty. Sexism. Gay Lib.

Corrections. Surveillance-Are all examined in this anthology of court cases and articles. The focus is the struggle for identity by both demographic and clientele groups against an often manipulative and dehumanizing beauracracy.

Random House February, 1973 256 pages $\$ 3.50$ paperbound

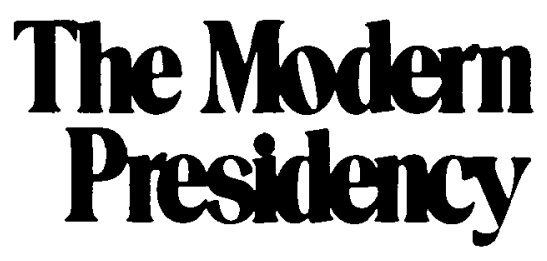

Nelson W. Polsby, University of California at Berkeley

Covering the last six administrations, this reader provides a realistic sense of the Presidency, showing how the office

is shaped by the man. The selections, written by politicians and journalists such as Joseph Kraft, R. W. Apple, and

Eric Sevareid, provide the flavor of each administration.

Random House 1973

256 pages $\$ 3.95$ paperbound

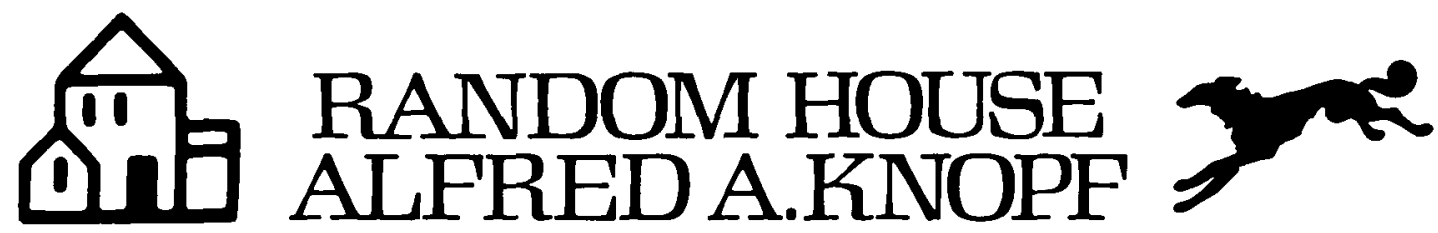

THE COLLEGE DEPARTMENT

457 HAHN ROAD, WESTMINSTER, MARYLAND 21157 


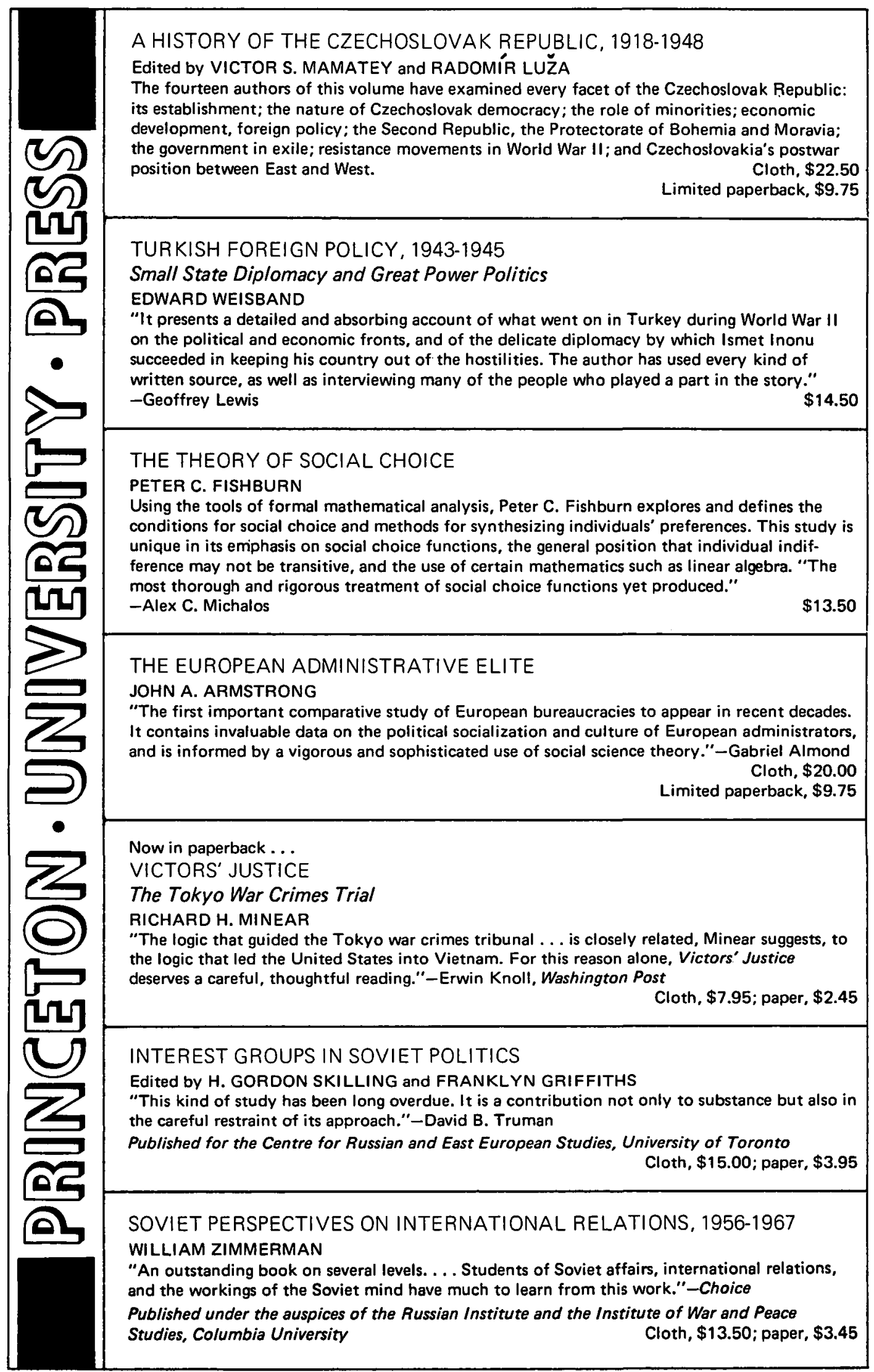




\title{
new from RIKA
}

The Research Institute on Korean Affairs

8555 16th Street, Silver Spring, Maryland 20910

\section{JOURNAL OF KOREAN AFFAIRS}

\author{
Editor Young Hoon Kang \\ Editorial Assistant Jae Eun Lee \\ Administrative Assistant Sherrill Malloy \\ Consulting Editors \\ Soon Sung Cho Chong Sik Lee \\ Joseph S. Chung Pong S. Lee \\ Ilpyong J. Kim Benjamin H. Min \\ Byung Chul Koh Rinn Sup Shinn \\ Dae Sook Suh
}

Journal of Korean Affairs is published quarterly by the Research Institute on Korean Affairs, 8555 16th Street, Silver Spring, Maryland 20910. The Institute, established in the fall of 1970 as a non-profit corporation with federal tax exemption status, has as its purpose: (1) Objective research and analysis in the field of Korean affairs for use by academic communities and educational institutions; (2) dissemination of authoritative information on Korean affairs to non-specialist individuals and organizations; and (3) establishment of a forum for professional discussion on Korean affairs. $\$ 6.00$ per year.

\section{GOVERNMENT AND POLITICS OF KOREA Introductory Readings and Essays}

\section{Edited by \\ Se-Jin Kim and Chang-Hyun Cho}

Historical Perspective on Korean Politics

Political Ideology and Korean Politics

Political Dissent in South Korea, 1948-61

National Government and Politics in South Korea

Bureaucracy and Local Government in South Korea

Political Parties and Elections in South Korea

Economic Development of South Korea

The Government and Power Structure of North Korea

The System of Local Government in North Korea

Economic Development of North Korea, 1945-70

North Korea's Foreign Policy

North Korea's Unification Strategy: An Assessment

The Korean Reunification Issue in the United Nations

$$
\begin{aligned}
& \text { BIBLIOGRAPHY } \\
& \$ 4.90
\end{aligned}
$$

\section{MAJOR POWERS AND KOREA}

Korea in Russia's East Asian Policy, Charles McLane

Chinese Policy Toward Korea, Harold C. Hinton

Comments by William Spahr, llpyong Kim, Soon Sung Cho, Nathan White, Chong Ik Kim, and Doe Sook Suh.

Korean in the Changing East Asian Policy of the United States, Bernard K. Gordon Japanese Policy Toward Korea, Young C. Kim

North Korean Policy Toward South Korea, Rinn-Sup Shinn

South Korean Policy Toward North Korea, Han-Kyo Kim

Korean Response to Major Power Rapprochement, Young Whan Kihl 
DECENTRALIZATION

AND SCHOOL EFFECTIVENESS

A Case Study of the 1969

Decentralization Law in New York City

\section{MELVIN ZIMET}

Foreword by David Rogers

Through a study of the decentralization process in one community school district in the South Bronx, the author views the effects it has had in terms on restructured authority and power relationships and of educational output. He explains how the failure of the Decentralization Law to reconcile the great differences between decentralization and community control planted the seeds of future conflict between the Community Board and the Central Board.

1973/186 pp./Cloth, \$8.50/Paper, $\$ 4.95$

\section{Also from Teachers College Press}

THE STUDENT/THE COLLEGE/THE LAW

William T. O'Hara/John G. Hill, Jr.

1972/220 pp./Cloth, \$8.50/Paper, $\$ 4.50$

EDUCATIONAL VOUCHERS

Concepts and Controversies

George R. LaNoue, Editor

1972/176 pp./Cloth, $\$ 8.50 /$ Paper, $\$ 3.50$

EDUCATIONAL INVESTMENT IN AN URBAN SOCIETY

Costs, Benefits, and Public Policy

Melvin R. Levin/Alan Shank, Editors

1970/425 pp./Cloth, \$12.5C/Paper, \$9.95

EDUCATION AND STATE POOLITICS

The Developing Relationship Between

Elementary-Secondary and Higher Education

Michael D. Usdan/David M. Minar/Emanuel Hurwitz, Jr.

1969/190 pp./Cloth, $\$ 7.50$

\section{tedChERS COLLEGE PRESS}

1234 Amsterdam Avenue New York, N.Y. 10027 


\section{NEW TOWNS IN-TOWN}

\section{Why a Federal \\ Program Failed}

Martha Derthick
"The book tells why the President who could send half a million men to war and drop all the bombs he wanted could not get a few creative, hopeful pilot housing projects built."

\section{-The Washington Monthly}

". . a short course in the failure of the program in particular and the federal bureaucracy in general."

- The New Republic

". . . a lucid but deeply disturbing insight into the workings and idle motions of our governmental machinery. Her little book conveys the depressing fascination of a Kafka novel."

-Wolf von Eckardt,

The Washington Post

$\$ 2.95$ paper

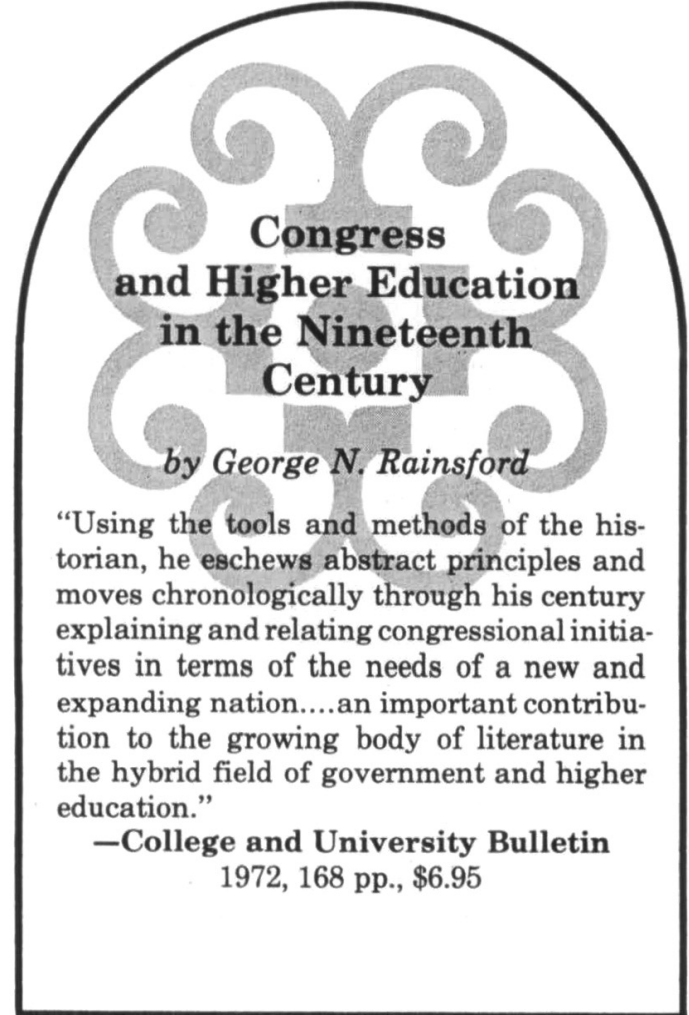

From your bookstore, or THE UNIVERSITY

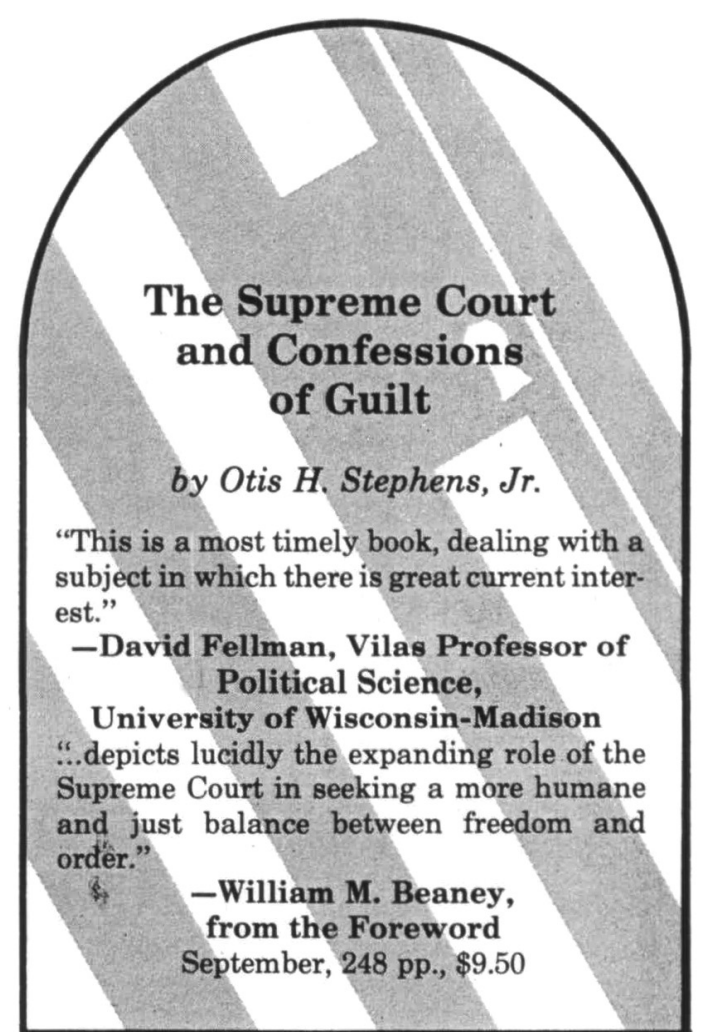

Tennessee Press Knoxville, Tennessee 
Send for our catalogues, available free of charge:

- Sales Catalogue 1973

- Check List of Books in Print 1945-1972

- Standing Order Service Guide

- United Nations Official Records 1962-1970

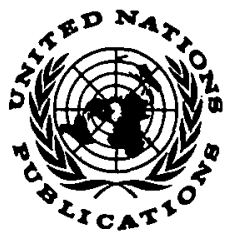

Supplement 1970-1972

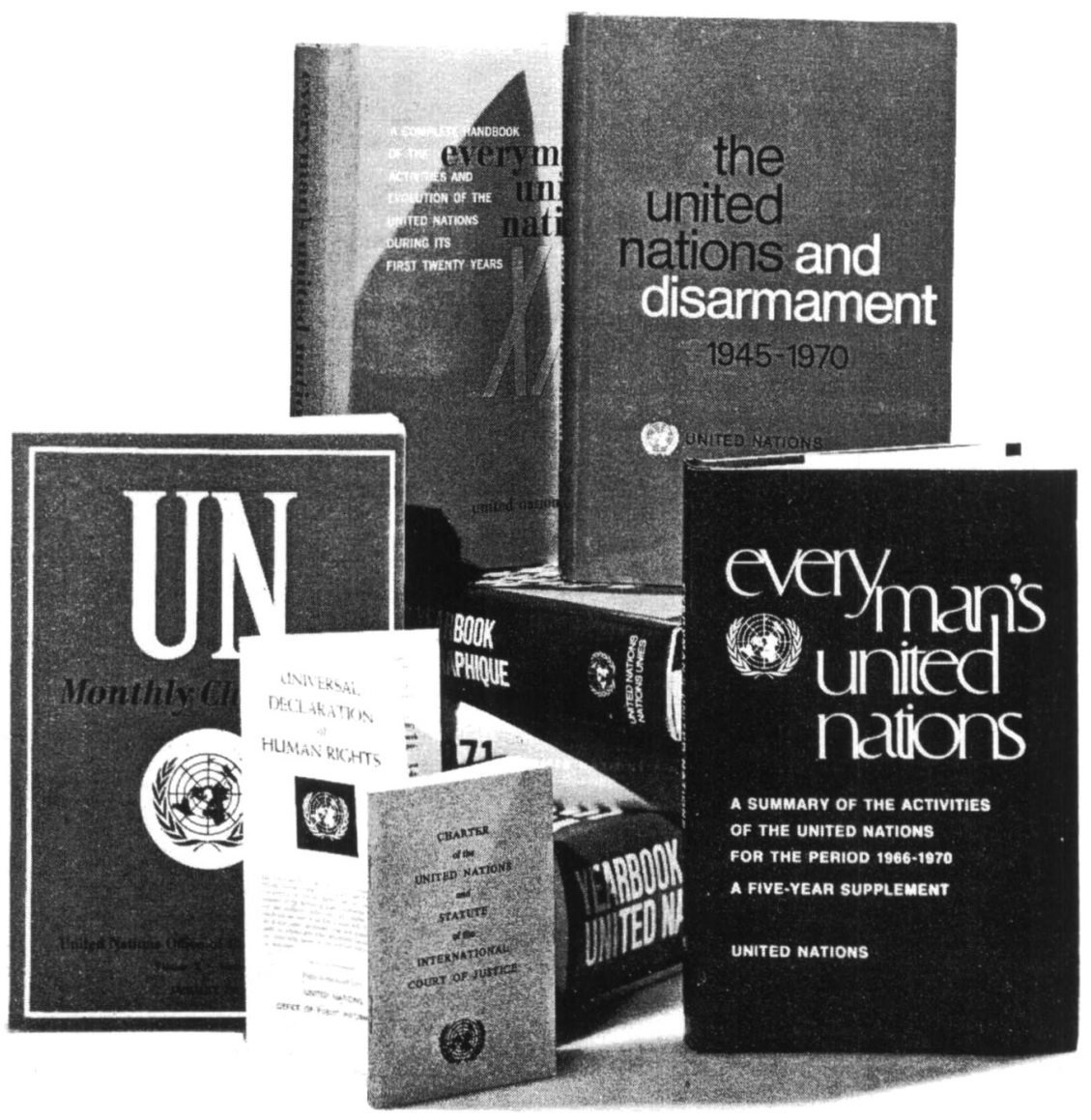

UNITED NATIONS PUBLICATIONS

Room LX-2300, New York, N.Y. 10017 or Palais des Nations, 1211 Geneva 10, Switzerland 


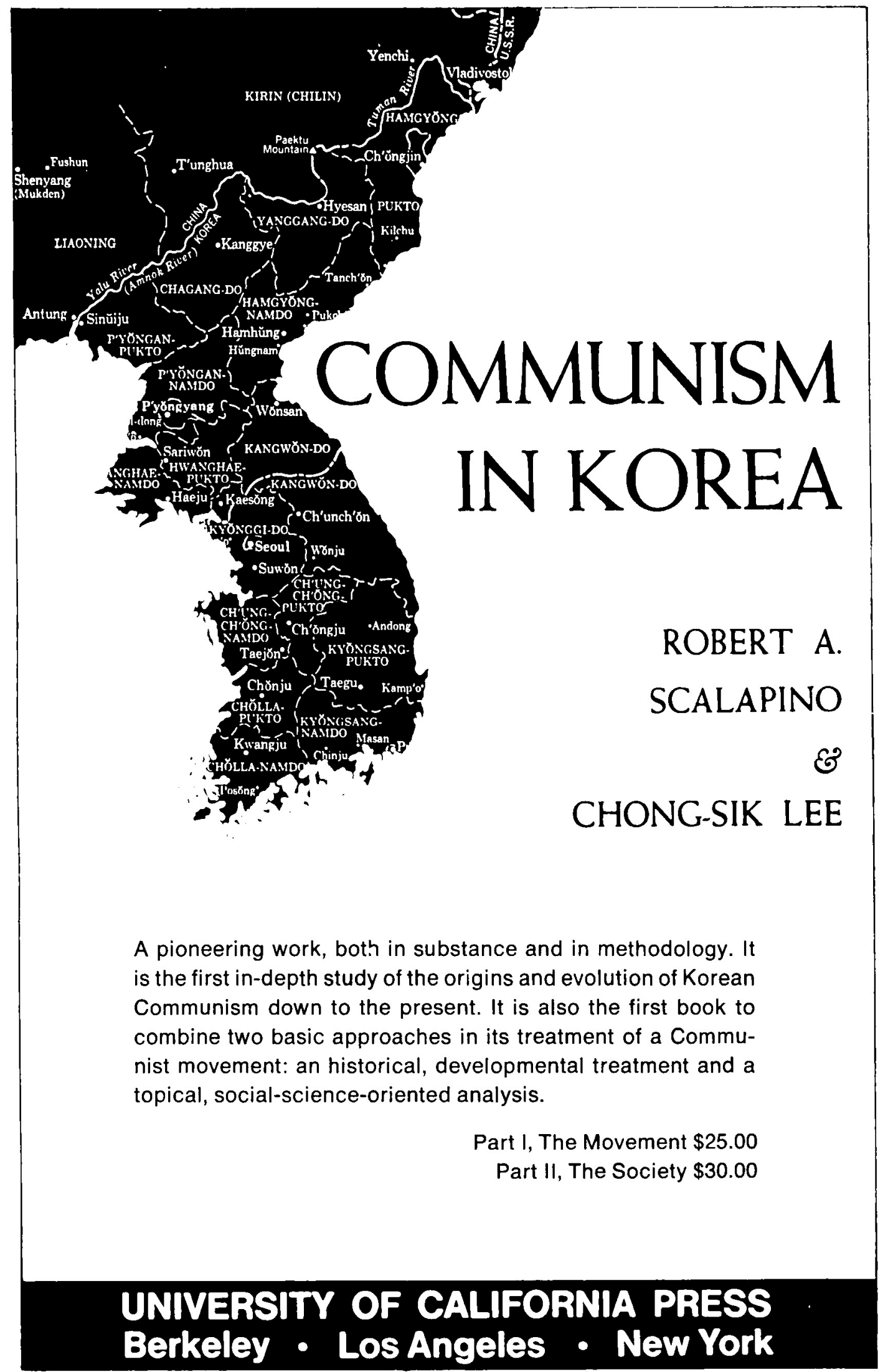




\section{POLITICAL SCIENCE FROM}

\section{Kentucky}

\section{UNITED STATES NATIONAL INTERESTS IN A CHANGING WORLD}

DONALD E. NUECHTERLEIN

“. . . presents a framework to assess our national interests in the 1970's; the basic concerns-defense, economy, and world order-are supplemented within this framework by transitory interests ranging in value from peripheral through major, vital, and survival. . . . The book makes careful use of the Pentagon Papers and other late sources. . . . well written, perceptive, and informative." -Library Journal $\$ 8.00$

\section{THE CRISIS OF DEMOCRATIC THEORY}

\section{Scientific Naturalism \& the Problem of Value}

EDWARD A. PURCELL, JR.

Winner of the 1972 Frederick Jackson Turner Award. "In this remarkable book, Purcell scrupulously records the long and continuing debate between ethical idealists and scientific naturalists over the status of democratic theory. . . . The scope of this work is immense. . . . it is remarkable that such far-reaching and complex material has been reduced to clear, readable prose." - Library Journal $\$ 11.50$

\section{DAMS, PARKS \& POLITICS}

\section{Resource Development \& Preservation in the Truman-Eisenhower Era} ELMO RICHARDSON

A chronicle of the myopia and gamesmanship that dominated Americans' understanding of their environment on the eve of the nation's ecology crisis. The author of The Politics of Conservation here examines the national park system, the development projects for the Columbia and Upper Colorado River Valleys, and the controversies over Hells Canyon, CVA, Olympic, Dinosaur, and Everglades national parks. / \$11.25.

\section{THE BANKING CRISIS OF 1933}

\section{SUSAN ESTABROOK KENNEDY}

Of special interest in this study is the author's examination of relations between Herbert Hoover and Franklin D. Roosevelt. Here is the first complete account of the events leading to and stemming from the nationwide banking "holiday" of March 1933. / (October) $\$ 13.25$

\section{THE POLITICS OF MOTION}

\section{The World of Thomas Hobbes}

THOMAS A SPRAGENS, JR. (FonEWORd By ANTHONY FLEW)

A penetrating analysis of the relationship between Hobbes' natural and civil philosophies. "The author's learning is both deep and broad, and his insights into many matters startlingly penetrating. This appears to me to be a permanent contribution to the analysis of political theory."-Russell Kirk / \$7.75

\section{THE UNIVERSITY PRESS OF KENTUCKY LEXINGTON 40506}




\section{Now in paperback...}

\section{the monumental best seller about}

\section{the tragic collision between the}

\section{Americans and the Vietnamese}

The most highly praised book of the year, this won the Pulitzer Prize, the National Book Award, the Bancroft Prize for history, and the

Sidney Hillman Award.

\section{FIRE IN THE LAKE:}

The Vietnamese and the Americans in Vietnam by FRANCES FITZGERALD

$\$ 2.25$

Other important new Vintage paperbacks of current interest

\section{The Politics of a Guaranteed Income:}

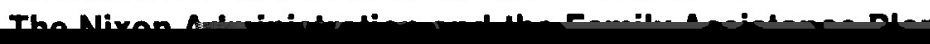

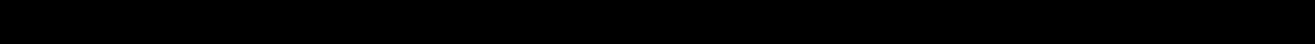
ever written by a high official of the decision-making process of this or any other government." - Edward C. Banfield, New Leader. "The book's richness of insight into the politics and psychology of governance, its capacity for making complex issues clear, its basic humaneness, its graceful and compelling style - these qualities give an uncommon luminosity to the complex and too often sullen world of modern policy making."

-Stephen K. Bailey, Political Science Quarterly. \$2.95

\section{World Without Borders}

by LESTER R. BROWN. The author of Seeds of Change proposes orastical strategies for coning with crucial 20th centinn nrohleme tional affairs one could imagine appearing at this time."

-Washington Post $\$ 2.95$

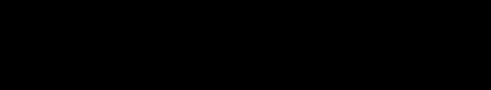

a division of Random House

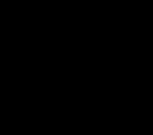




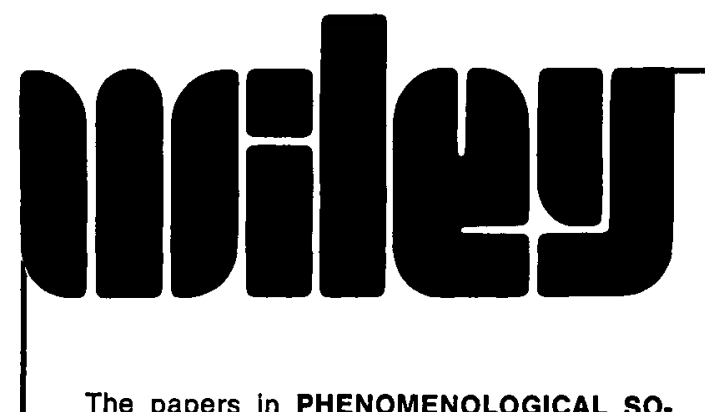

The papers in PHENOMENOLOGICAL SOCIOLOGY: Issues and Applications provide an advanced and comprehensive introduction to the phenomenological approach to social science theory. Specially written by practicing philosophers and social scientists, they span a broad range of contemporary sociological issues including communication, interaction, organization, and groups and society.

Edited by George Psathas, Boston University, with contributions by Egon Bittner, Alexander D. Blumenstiel, Fred R. Dallmayr, Horacio Fabrega, Jr., Roger Jehenson, Peter K. Manning, John O'Neill, Herbert Spiegelberg, Helmut R. Wagner, Frances C. Waksler, Kurt H. Wolff, and Richard M. Zaner

$$
1973 \quad 368 \text { pages }
$$

$\$ 12.50$

An important contribution to the study of American politics, NONPARTISAN ELECTIONS AND THE CASE FOR PARTY POLITICS presents the first large-scale, comparative study of nonpartisan elections, and develops a theory relating the consequences of electoral institutions to the structural characteristics of communities. One of the few discussions of political party reform at the local level is included, and an attempt is made to move the debate concerning the advantages and disadvantages of stronger political parties from the realm of democratic theory to the arena of group conflict. A volume in the Wiley Series in Urban Research, edited by Terry N. Clark

By Willis D. Hawley, Duke University

1973224 pages

$\$ 9.95$

In THE SOCIAL CONTEXTS OF RESEARCH, a stimulating collection of original essays, ten recognized scholars of science and research join the editors in considering the social organization of research and its role in contemporary society. Some of the issues confronted are: Patterns of the Institutionalization of Research; Politics and Research; Economics of Research; and Relations $\mathrm{Be}$ tween Researchers and Practitioners.

Edited by Saad Z. Nagi and Ronald G. Corwin, both of The Ohio State University 1972409 pages $\$ 13.50$

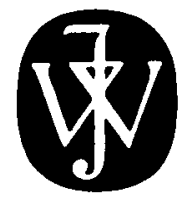

Based on a national survey of religious groups in both rural and urban areas, ETHNIC DIVERSITY IN CATHOLIC AMERICA describes, analyzes, and explains the sociological, religious, and marital behavior of Catholic ethnic groups. By integrating empirical sociology and survey research with social history, it documents the persistence of ethnic diversity in Catholic America, taking ethnic diversity in American life as its unifying thesis. The result is an engrossing study of Catholic ethnic life, and a fresh examination of the ethnic factor in America. By Harold J. Abramson, University of Connecticut $1973 \quad 224$ pages $\$ 11.95$

Two volumes in Comparative Studies in Behav. ioral Science: A Wiley Series, edited by Robert T. Holt and John E. Turner

Based on a recently compiled multiple cross-section of data on more than $100 \mathrm{na}$ tions, MASS POLITICAL VIOLENCE: A Cross-National Causal Analysis examines the causal processes underlying differences across nations in levels of mass political violence since World War II. It centers on domestic violence at the macro-political level, focusing on events of an anti-system nature, of immediate political significance, that involved collectivities.

By Douglas A. Hibbs, Jr., Massachusetts Institute of Technology

$$
1973 \quad 288 \text { pages } \$ 13.95
$$

CROSS-CULTURAL RESEARCH METHODS presents-for the first time in a single volume-a cohesive, logically-organized discussion of the strategies, methodologies, and problems involved in planning and conducting cross-cultural research projects. Relevant to behavioral scientists throughout the world, it emphasizes empirical approaches and the proper selection of methods and tools to factlitate meaningful deta collection and to insure valid comparlsons of Indlvidual behavlor across cultures. In two parts it covers: general topics, such as sampling, translation of instruments, survey methods, etc.; and specific techniques, including cross-culturally appropriate psychological tests and factor analytic and other multivariate techniques.

By Richard W. Brislin, Culture Learning Institute of the East-West Center, Honolulu, and Walter J. Lonner and Rober M. Thorndike, both of Western Washington State College $\quad 1973 \quad 351$ pages $\$ 16.95$

All books are available from your bookseller or from Dept. 093-A 4060-WI

WILEY-INTERSCIENCE

a division of JOHN WILEY \& SONS, Inc. 605 Third Avenue, New York, N. Y. 10016 In Canada:

22 Worcester Road, Rexdale, Ontario

Prices subject to change without notice 


\section{New and}

recently published-

\section{Winthrop has the books you need for courses in:}

$\square$ AMERICAN GOVERNMENT \& PUBLIC POLICY

$\checkmark$ DAVID C. SAFFELL

The Politics of American National Government

Lucid, concise and lively, this introductory text balances factual material with analysis of behavioral trends. It offers a systems approach, a discussion of current policy issues in every chapter, up-to-date statistical information through November 1972, and integrated readings which illustrate key concepts.

INSTRUCTOR'S MANUAL AVAILABLE. January 1973, paper $\$ 6.50$

$\checkmark$ PHILIP H. MELANSON

Knowledge, Politics, and Public Policy: Introductory Readings in American Politics

March 1973, paper $\$ 4.95$

$\checkmark$ FRANKLIN TUGWELL

Search for Alternatives: Public Policy and the Study of the Future

March 1973, paper $\$ 5.95$

CFRED KRAMER

Perspectives on Public Bureaucracy: A Reader on Organization January 1973, paper $\$ 3.95$

$\sim$ JAMES BURKHART et al

Strategies for Political Participation 1972 , paper $\$ 2.95$

V RAYMOND L. LEE and DOROTHY A. PALMER America in Crisis: Contemporary Political Dilemmas 1972, paper $\$ 4.95$

\section{$\square$ URBAN POLITICS}

MURRAY STEDMAN, JR.

Urban Politics

(In less than a year, this has become THE book in the field!) 1972, paper $\$ 6.40$, cloth $\$ 7.95$

\section{$\square$ INTERNATIONAL POLITICS}

$\sim$ ROBERT J. LEIBER

Theory and World Politics

1972 , paper $\$ 3.95$, cloth $\$ 6.95$

$\checkmark$ STEVE L. SPIEGLE and KENNETH N. WALTZ

Conflict in World Politics

1971 , paper $\$ 4.95$, cloth $\$ 7.50$

W WAYNE WILCOX, LEO ROSE, AND R. GAVIN BOYD

Asia and the International System

1972, paper $\$ 5.95$, cloth $\$ 7.95$

WINTHROP PUBLISHERS, Inc. 17 Dunster Street at Harvard Square Cambridge, Massachusetts 02138 


\section{And there are more coming-}

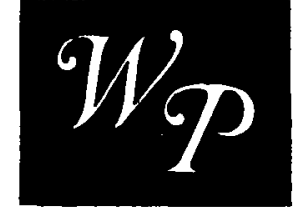

\section{Winthrop will publish these important books in 1974:}

\footnotetext{
THE LOGIC OF INTERNATIONAL SOCIETY

Steven Rosen, Brandeis University, and Walter S. Jones, Northeastern University

$\sim$ INTRODUCTION TO AFRICAN POLITICS

Carl S. Rosberg, University of California at Berkeley

$\sim$ POLITICS OF DEVElOPING NATIONS

David E. Schmitt, Northeastern University

$\checkmark$ THE BLACK IN THE AMERICAN POLITICAL SYSTEM

Lucius B. Barker, Washington University

$\sim$ POLITICAL CONCEPTS IN AMERICA

Gordon E. Baker, University of California at Santa Barbara

- INTROduction TO PUBLIC POLICY

Robert H. Binstock and Peter Woll, both of Brandeis University

POLITICS, PARTIES aND PRESSURE GROUPS

L. Harmon Zeigler, University of Oregon, and Joseph Olexa, Linfield College

$\checkmark$ POLITICS OF CONSTITUTIONAL LAW

Martin Shapiro, Harvard University, and Douglas Hobbs, University of California at Los Angeles

$\checkmark$ INTRODUCTION TO POLITICAL SCIENCE

David E. Apter, Yale University

INTRODUCTION TO PUBLIC ADMINISTRATION

Fred Kramer, University of Massachusetts, Amherst

THE UNITED STATES AND EUROPE

Wolfram Hanreider, University of California at Santa Barbara

$\checkmark$ POLITICAL FUTURES

Leon Lindberg, University of Wisconsin
}

For more information, write to Richard Marran at:

\section{WINTHROP PUBLISHERS, Inc. 17 Dunster Street at Harvard Square Cambridge, Massachusetts 02138}


New from Yale

The Beliefs of Politicians

Ideology, Conflict, and Democracy in Britain and ltaly by Robert D. Putnam

As the Watergate scandal has recently shown, the character of a country's leadership deeply affects the patterns of its politics. This study is a systematic analysis of interviews with 176 members of the British House of Commons and the Italian Chamber of Deputies that probes some of the fundamental beliefs and values of political leaders in these two contrasting democracies. In addition to providing a sophisticated refinement of the notions in the political culture literature, Mr. Putnam's work illustrates how intensive interview material can be sensitively analyzed in ways rigorous enough to meet the standards of modern, quantitative social science. "A first-rate book that will make an important contribution to political science." - Sidney Verba October publication $\$ 10.95$

\section{Building an Austrian Nation}

The Political Integration of a Western State by Willam T. Bluhm

Once the crown lands of a dynastic empire, briefly after World War I an independent republic of confused identity, and subsequently an eastern appendage of Hitler's Germany, Austria since 1945 has become a modern democratic nation-state. In this detailed examination of recent Austrian political history, Mr. Bluhm uses concepts from the contemporary literature of nation building and political development and tests some of its leading hypotheses. He finds a striking parallel between the Austrian experience and the circumstances of today's emerging non-Western states. "An excellent example of a theoretically significant case study that deserves to be read by all scholars in the field of comparative government and particularly those working on the questions of nation.building and political development."-Arend Lijphart $\$ 9.75$

\section{The French Colonial Myth and Constitution-Making in the Fourth Republic}

by D. Bruce Marshall

A compelling synthesis of political science and history, this study examines the impact of the French colonial myth on the political elite during the constitutional crisis of 1946. It traces the evolution of the colonial myth over more than a century during which it profoundly influenced the values, perceptions, and goals of both metropolitan and native leaders. It also dissects the strategies of de Gaulle, the French Communists, the native deputies, and the other parties to the constitutional debate, showing how each sought to bargain for institutions that fit its own view of France's colonial role. French internal and international politics are described to help explain the failure of French leaders to grasp the nature of colonial nationalism and their inability to find a peaceful path to decolonization. $\$ 12.50$

\section{Authoritarian Brazil}

Origins, Policies, and Future edited by Altred Stepan

The development model followed by the military regime that came to power in Brazil in 1964 is one of the most controversial among the less developed countries. The regime's authoritarian structure, combined with a GNP growth rate that is one of the highest in the world, raises extremely disturbing yet fundamental questions about the relation between political authoritarianism and economic dynamism. In this book, social scientists from three continents assess the major political and economic characteristics of the Brazilian model. Because events here have important implications for other countries, there is a deliberate search throughout the volume for new conceptual frames of reference to help put the Brazilian process in a larger perspective. There is also an attempt to be explicit about what values the regime promotes and what values it denies. December publication $\$ 10.00$

\section{Yale University Press New Haven and London}




\section{From Rand MC Nally}
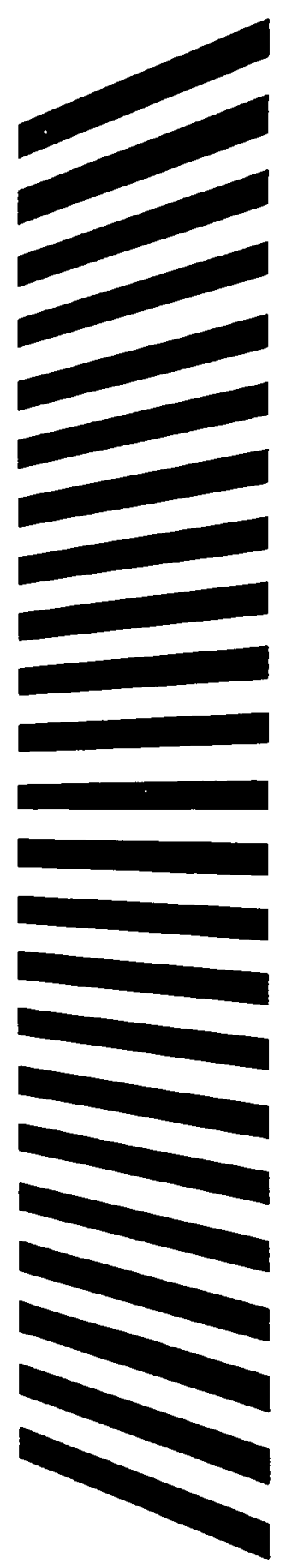

DEMOCRACY IN THE UNITED STATES:

Promise and Performance

Second Edition

Robert A. Dahl, Yale University

Professor Dahl insightfully describes, explains, and appraises the American political system in terms of its promise and performance. In doing so, he provides students with a comprehensive introduction to American government - its structure, development, democratic foundations, and unique qualities - and a perspective from which to evaluate the gap between the ideal and the reality of American democracy. Instructor's Manual available.

453 pages / $\$ 7.50$ Paper

\section{Three New Markham Books}

\section{AMERICAN IDEOLOGIES}

The Competing Political Beliefs of the 1970s Second Edition

Kenneth M. Dolbeare, University of Washington and Patricia Dolbeare, with Jane Hadley, University of Washington

The second edition of this highly successful text continues its treatment of the role of ideology in the U.S:, viewing established political ideologies in relation to what's happening today. Challenges by the counterideologies of Blacks, Chicanos, Indians, Women's Lib, the New Left, and various democratic and revolutionary socialists, comprise the new material of this expanded edition.

\section{0 pages / \$3.50 Paper / \$7.95 Cloth}

\section{READINGS IN AMERICAN IDEOLOGIES}

Edited by Kenneth M. Dolbeare, University of Washington, Patricia Dolbeare, and Jane Hadley, University of Washington

Designed to complement the Second Edition of American Ideologies, this new reader contains original works by major authors on current ideologies and ideas in U.S. society and the political arena. Includes chapters on Minority Liberation, Women's Liberation, and The New Left, as well as on the mainstream political beliefs.

355 pages / \$3.50 Paper / \$7.95 Cloth

AMERICAN NATIONAL GOVERNMENT: An Introduction to Political Institutions

Robert S. Ross, Chico State College

Presented clearly and concisely in this small volume are the basic structural components of federal government. Introductory chapters discuss the framing of the Constitution and its underlying principles.

224 pages / \$2.95 Paper / \$7.95 Cloth

\section{RAND MÇNALLY COLLEGE PUBLISHING COMPANY Box 7600, Chicago, Illinois 60680}

